\title{
Meteoric Beryllium-10 in Miocene permafrost and the onset of persistent polar aridity in East Antarctica
}

Marjolaine Verret ( $\square$ Marjolaine.Verret@vuw.ac.nz )

Victoria University of Wellington https://orcid.org/0000-0002-3857-526X

Cassandra Trinh-Le

Victoria University of Wellington

Warren Dickinson

Victoria University

Kevin Norton

Denis Lacelle

University of Ottawa

Marcus Christl

ETH Zürich https://orcid.org/0000-0002-3131-6652

Richard Levy

GNS Science

Tim Naish

Victoria University of Wellington

Article

Keywords: permafrost, ground ice, Friis Hills, Table Mountain, University Valley

Posted Date: October 12th, 2021

DOI: https://doi.org/10.21203/rs.3.rs-912484/v1

License: (c) (i) This work is licensed under a Creative Commons Attribution 4.0 International License.

Read Full License 


\section{Meteoric Beryllium-10 in Miocene permafrost and the onset of persistent polar aridity in East Antarctica}

Marjolaine Verret ${ }^{1 *}$, Cassandra Trinh-Le ${ }^{2}$, Warren Dickinson ${ }^{1}$, Kevin Norton $^{2}$, Denis Lacelle ${ }^{3}$, Marcus Christ ${ }^{4}$, Richard Levy ${ }^{15}$, Tim Naish ${ }^{1}$

${ }^{1}$ Antarctic Research Centre, Victoria University of Wellington, New Zealand.

${ }^{2}$ School of Geography, Environment and Earth Sciences, Victoria University of Wellington, New Zealand.

${ }^{3}$ Department of Geography, Environment and Geomatics, University of Ottawa, Canada.

${ }^{4}$ Department of Physics, Laboratory of Ion Beam Physics, ETH Zürich, Switzerland

${ }^{5}$ GNS Science, Lower Hutt, New Zealand

* Corresponding author: Marjolaine.Verret@vuw.ac.nz

Key words: permafrost, ground ice, Friis Hills, Table Mountain, University Valley 


\section{Abstract}

Continental scale ice sheets have occupied Antarctica since the major global cooling across the Eocene/Oligocene boundary $\left(\sim 33.9 \mathrm{Ma}^{1}\right)$. However, the timing and nature of the transition to a relatively stable and persistent terrestrial East Antarctic Ice Sheet that characterises the modern environment remains disputed. Although proxy data show global surface temperatures remained significantly warmer through the late Miocene than today, the hypothesis that the upper elevations of the McMurdo Dry Valleys remained under a hyper-arid polar climate since the mid-Miocene has persisted ${ }^{2,3}$. Here, we constrain the onset of polar aridity in the McMurdo Dry Valleys region using meteoric Beryllium-10 as a tracer of water infiltration in mid-Miocene and late Quaternary-age soils at three sites situated $>1000 \mathrm{~m}$ a.s.1.. Our results show that meteoric Beryllium-10 infiltrated the soils for a period after sediment emplacement $15.0-14.0 \mathrm{Ma}$, terminating at $\sim 6.0 \mathrm{Ma}$. Reconstruction of climate from paleo-active layer thickness and threshold of mobility of ${ }^{10} \mathrm{Be}_{\text {met }}$ suggests that at $6.0 \mathrm{Ma}$, summer temperatures were $7-10^{\circ} \mathrm{C}$ with annual precipitation $>10 \mathrm{~mm}$. Polar aridity at high elevations has persisted since $\sim 6.0 \mathrm{Ma}$, well after previous reconstructions $(13.8-12.5 \mathrm{Ma})$. Together, our findings indicate that high elevations of the McMurdo Dry Valleys experienced interval(s) of warm-wet climate between $\sim 14.0-6.0$ Ma which reconciles observations of coastal warmth and reduced ice in the Ross Embayment ${ }^{4}$. 


\section{Main}

Meteoric Beryllium-10 ( $\left.{ }^{10} \mathrm{Be}_{\mathrm{met}}\right)$, a tracer of water infiltration and its migration in soils, has been used to assess the onset of persistent aridity in the McMurdo Dry Valleys (MDV) and East Antarctica ${ }^{3,5,6}$. Meteoric ${ }^{10} \mathrm{Be}$ is formed in the upper atmosphere by cosmic ray-induced spallation of oxygen, producing ${ }^{10} \mathrm{BeO}$ and ${ }^{10} \mathrm{Be}(\mathrm{OH})_{2}$ which adhere to atmospheric aerosols and are transferred to Earth's surface by wet (rain or snow) or dry deposition (dust) ${ }^{7}$. Through continued deposition, ${ }^{10} \mathrm{Be}_{\text {met }}$ accumulates at the surface and, at most natural $\mathrm{pH}$ levels $(\mathrm{pH}>4)$, adsorbs onto fine soil particles that are translocated below the surface by infiltration and clay illuviation ${ }^{8}$. This, along with the predictability of atmospheric flux, makes ${ }^{10} \mathrm{Be}_{\text {met }}$ a suitable environmental tracer of water movement and its residence time through soil profiles over million-year timescales ${ }^{3,6}$.

While the coastal zone in the Ross Embayment has experienced periods of warmth that coincide with sea ice melt and retreat of the West Antarctic Ice Sheet during past interglacials ${ }^{4}$, the high elevations of the MDV, known as the stable upland or ultraxerous zone ${ }^{9}$, are thought to have remained unglaciated under a cold hyper-arid climate since $\sim 12.5-13.8 \mathrm{Ma}^{2,3,10,11}$. Ground ice and ${ }^{10} \mathrm{Be}_{\text {met }}$ in permafrost sediments from high elevations have the potential to record the onset of polar aridity in these inland regions and to record climatic conditions during the late Miocene and Pliocene.

New data presented in this paper allows us to reconcile the apparent conflict between observations and interpretations at high inland and low coastal locations. Numerical modeling suggests that the uppermost tens of meters of permafrost soils should be largely free of ground 
ice due to its sublimation under hyper-arid climate ${ }^{12,13}$. However, recent studies documented the widespread presence of ice-cemented permafrost soils that were inferred to have formed through infiltration and freezing of evaporated snowmelt ${ }^{14-16}$. This hyper-arid ground ice conundrum is further highlighted by ${ }^{10} \mathrm{Be}_{\text {met }}$ measurements from Miocene-age ultraxerous permafrost soils. Significant ${ }^{10} \mathrm{Be}_{\text {met }}$ concentrations $\left(\left[{ }^{10} \mathrm{Be}\right.\right.$ met $]$ ) down to at least $4.5 \mathrm{~m}$ at Table Mountain suggest infiltration of liquid water during a warm period well after $12.5 \mathrm{Ma}^{6}$. Conversely, the hypothesis of persistent polar aridity following the deposition of sediment between 14 and 17.5 Ma at Friis Hills was made based on a single measurement of ${ }^{10} \mathrm{Be}_{\text {met }}$ below the blank range at $60 \mathrm{~cm}$ of $\operatorname{depth}^{3}$.

Here, we report 64 new ${ }^{10} \mathrm{Be}_{\text {met }}$ measurements from 10 boreholes obtained in mid-Miocene and late Quaternary-age icy permafrost soils at three sites in the upper MDV (Fig. 1). By using

$\left[{ }^{10} \mathrm{Be}_{\mathrm{met}}\right]$ from boreholes at the two mid-Miocene sites, we constrain the timing and magnitude of water infiltration in these soils since the mid-Miocene and show that the high elevations of the MDV have not remained frozen over the past $15 \mathrm{Myr}$.

\section{Meteoric Beryllium-10 in the McMurdo Dry Valleys permafrost}

The stable upland zone of the MDV is a cold hyper-arid desert environment where maximum air temperatures remain below $0^{\circ} \mathrm{C}$, and precipitation is limited to $\sim 3.0-14.0 \mathrm{~mm}$ snow water equivalent (swe) that quickly sublimates or is removed by katabatic winds ${ }^{9,17}$. Cores were collected from three sites in this zone: Friis Hills, Table Mountain and University Valley (Fig. 1). The Friis Hills $\left(77^{\circ} 45^{\prime} \mathrm{S}, 161^{\circ} 30^{\prime} \mathrm{E} ; 1200\right.$ - $1500 \mathrm{~m}$ a.s.l.) are a $12 \mathrm{~km}$-wide inselberg at the head of Taylor Valley ${ }^{18}$. Surficial deposits at Friis Hills consist of a $\sim 80 \mathrm{~m}$ thick sequence of glacial 
drifts interbedded with lacustrine sediments, originating from the advance and retreat of a local alpine glacial system connected to the EAIS ${ }^{18} \cdot{ }^{40} \mathrm{Ar} /{ }^{39} \mathrm{Ar}$ dating of tephra layers and paleomagnetic reversal stratigraphy indicate the sequence spans the interval from $\sim 15.0$ to 14.0 $\mathrm{Ma}^{19}$. The sediment therefore captures the transition from the end of the Miocene Climatic Optimum (MCO; 17.0 - 14.8 Ma) and the progressive cooling of the Middle Miocene climate transition (MMCT; 14.8 - 13.8 Ma; Fig. 2) ${ }^{20-22}$. Table Mountain (775 $57^{\prime} \mathrm{S}, 161^{\circ} 57^{\prime} \mathrm{E} ; 1800-$ $1945 \mathrm{~m}$ a.s.l) is located on the southern side of the Ferrar Glacier, bounded southwest by Tedrown Glacier and east by Emmanuel Glacier ${ }^{23}$ (Fig. 1). Surficial deposits consist of Sirius Group sediments, overlying Beacon Supergroup sediments. Although the age of the Sirius Group has been debated, stratigraphic relationships ${ }^{2,24},{ }^{40} \mathrm{Ar} /{ }^{39} \mathrm{Ar}$ dating of tephra layers ${ }^{25}$ and cosmogenic exposure ages ${ }^{26}$ indicate that the deposit at Table Mountain likely predates 15.0 Ma. University Valley $\left(77^{\circ} 52^{\prime} \mathrm{S}, 160^{\circ} 45^{\prime} \mathrm{E} ; 1600-1800 \mathrm{~m}\right.$ a.s.1.) is a hanging glacial valley situated $\sim 450 \mathrm{~m}$ above the floor of Beacon Valley with late Quaternary-age surficial sediments that originate from the weathering of the Beacon Supergroup sandstone ${ }^{15}$ (Fig. 1). Surface sediments in University Valley comprising undifferentiated till and alpine drift and are Quaternary in age based on optically stimulated luminescence ${ }^{27}$. At all three sites, $20-70 \mathrm{~cm}$ of dry permafrost overlies ice-cemented permafrost that often contains ground ice above pore-saturation ${ }^{14-16}$. Due to cold summers, an active layer $<5 \mathrm{~cm}$ develops at these sites $^{28}$.

Average surface $\left[{ }^{10} \mathrm{Be}_{\mathrm{met}}\right]$ is $1.06 \times 10^{8}$ atoms $\mathrm{g}^{-1}$ at Friis Hills (sites $2 \mathrm{C}, \mathrm{C} 2$ and FA; Tables $\mathrm{S} 1$ and S3), $4.75 \times 10^{8}$ atoms $\mathrm{g}^{-1}$ at Table Mountain (Table S3) and $1.19 \times 10^{9}$ atoms $^{-1}$ at University Valley (Table S2). The order of magnitude increase at University Valley is likely due to its morphology which makes it a better catchment for ${ }^{10} \mathrm{Be}_{\text {met }}$-rich dust and aerosols than other 
sites in the $\mathrm{MDV}^{5}$. At all sites, $\left[{ }^{10} \mathrm{Be}_{\mathrm{met}}\right]$ decreases by one or two orders of magnitude immediately below the surface, but concentrations remain above analytical blank (Fig. 3a). $\left[{ }^{10} \mathrm{Be}_{\mathrm{met}}\right]$ profiles in the Miocene sites, Friis Hills and Table Mountain, displayed similar trends with depth. The ${ }^{10} \mathrm{Be}_{\text {met }}$ profiles were separated into three groups (near-surface, intermediate and deep) with the boundary between near-surface and intermediate groups at $227 \mathrm{~cm}$ at Friis Hills and $349 \mathrm{~cm}$ at Table Mountain (Figs $3 \mathrm{~b}$ and 4). The $\left[{ }^{10} \mathrm{Be}_{\mathrm{met}}\right]$ depth curve within the near-surface group is characterised by equation $\mathrm{y}=5.03 \times 10^{6} \mathrm{e}^{-0.0108 \mathrm{x}}\left(\mathrm{r}^{2}=0.92\right)$ at Friis Hills and $\mathrm{y}=2.50 \times$ $10^{7} \mathrm{e}^{-0.0116 \mathrm{x}}\left(\mathrm{r}^{2}=0.93\right)$ at Table Mountain (Fig. 4). The ${ }^{10} \mathrm{Be}_{\mathrm{met}}$ within the intermediate group reached a steady-value of $4.26 \times 10^{5}$ atoms $\mathrm{g}^{-1}$ at Friis Hills and $4.45 \times 10^{5}$ atoms $\mathrm{g}^{-1}$ at Table Mountain (Fig. 4). The $\left[{ }^{10} \mathrm{Be}_{\mathrm{met}}\right]$ in the deep group (below $35 \mathrm{~m}$ at Friis Hills) were statistically lower than in the intermediate group samples (p-value $<0.05$ ), varying between 1.33 and $4.31 \times$ $10^{5}$ atoms g-1 (avg. $2.10 \times 10^{5}$ atoms g-1 Fig 3b)

\section{Onset of polar aridity in the McMurdo Dry Valleys}

The abrupt decrease in ${ }^{10} \mathrm{Be}_{\text {met }}$ of one to two orders of magnitude directly below the surface at all sites suggests little to no disturbance of the regolith at least throughout the late Quaternary. However, since $\left[{ }^{10} \mathrm{Be}_{\mathrm{met}}\right]$ remains detectable in the two profiles in the Miocene sediments, it can be used to solve for closure age (i.e. time when ${ }^{10} \mathrm{Be}_{\text {met }}$ stopped infiltrating the ground and was sealed-off in the sediment profile; Fig S3) and to calculate erosion rates (see Methods). The

${ }^{10} \mathrm{Be}_{\text {met }}$ decay curves at Friis Hills and Table Mountain suggest two active periods of water infiltration: the sediments above $227 \mathrm{~cm}$ at Friis Hills and above $349 \mathrm{~cm}$ at Table Mountain both closed-off at $\sim 6.0 \pm 0.5 \mathrm{Ma}$; the intermediate sections closed-off at the latest $\sim 12.0 \mathrm{Ma}$ at Friis Hills and at the latest at $\sim 16.0$ Ma at Table Mountain; and the samples below $40 \mathrm{~m}$ at Friis Hills 
were sealed-off from surface infiltration at the latest at $\sim 14.0 \mathrm{Ma}$. In sediments, ${ }^{10} \mathrm{Be}_{\text {met }}$ is transported by: (1) mechanical transport of ${ }^{10} \mathrm{Be}_{\text {met }}$ absorbed to clays, which translocate by percolating water, or (2) solutional transport of ${ }^{10} \mathrm{Be}_{\text {met }}$ if soil $\mathrm{pH}$ is $<3\left[{ }^{29}\right]$. Solutional transport at our three sites can be ruled out as soil $\mathrm{pH}$ generally ranges between 7.5 and 9.5 in the $\mathrm{MDV}^{30}$. Whereas lower $\mathrm{pH}$ values of 5 to 6 are recorded in highly nitric soils ${ }^{30}$, they are still too alkaline to support solutional transport. We acknowledge that major volcanic eruptions can decrease the $\mathrm{pH}$ of snow meltwater to $3.5-4.5$ for 1 to 10 years $^{31}$, but these eruptions must occur in close proximity to the site for substantial accumulation of acidic fallout and even if these conditions were met, $\mathrm{pH}$ would still remain above the ${ }^{10} \mathrm{Be}$ met solubility threshold.

Unfrozen water in permafrost sediments can migrate under thermal-stress gradients and Van der Waals force ${ }^{32}$. However, this unfrozen water cannot translocate clays and hence mobilize ${ }^{10} \mathrm{Be}_{\mathrm{met}}$ $\left[{ }^{8}\right]$. Therefore, the presence of ${ }^{10} \mathrm{Be}_{\text {met }}$ at depth at the two Miocene-age study sites requires translocation under conditions where permafrost was absent or where an active layer developed above the frozen sediment. Both of these conditions require a climate that is warmer and wetter than today. At Friis Hills, the similar ${ }^{40} \mathrm{Ar} /{ }^{39} \mathrm{Ar}$ ages of tephras in the sediments ( $\sim 5$ to $27 \mathrm{~m} ; 14.0$ $-15.0 \mathrm{Ma})$ and the ${ }^{10} \mathrm{Be}_{\text {met }}$ closure ages in the deep ( 30 to $\left.40 \mathrm{~m} ;<14.0 \mathrm{Ma}\right)$ groups implies that the infiltration of water could have happened more or less simultaneously with the deposition of the sediments and near-synchronous aggradation of permafrost ${ }^{16}$. The same inference can be drawn from the Table Mountain site where the maximum closure age of $\sim 16.0$ Ma coincides with the mid-Miocene age of the sediment ( 15.0 Ma). However, the near-surface regolith at Friis Hills and Table Mountain ( $\sim 2$ to $3.5 \mathrm{~m}$ ) have a closure age of $6.0 \pm 0.5 \mathrm{Ma}$, which challenges the assumption that the high elevations of the MDV remained frozen under cold hyper-arid climate 
since the MMCT. The closure age of $6.0 \pm 0.5 \mathrm{Ma}$ suggests that the late Miocene was either (1) continuously favorable to water infiltration and translocation of clays in an active layer or (2) mostly under cold-dry conditions but punctuated with warmer-wetter intervals. Erosion rate estimates from high elevation bedrock sites across Antarctica seem to support the second scenario with enhanced erosion at specific time intervals (e.g. a $\sim 250$ ky period favorable to erosion at ca. $5.0 \mathrm{Ma})^{33}$. Nevertheless, in either scenario, the conditions that allow translocation of clays in soils stopped at $6.0 \pm 0.5 \mathrm{Ma}$ when and the climate switched to persistent polar aridity.

Climate and soil conditions that allow the translocation of ${ }^{10} \mathrm{Be}$ met in soils are poorly defined, especially for cold hyper-arid environments, since they depend heavily on micro-scale mechanical processes. Conceptual models on colloid mobility in unsaturated sediments suggest that a critical water content is needed for initiation of mobilization ${ }^{34}$. A study from the warm hyper-arid Atacama Desert in Chile where mean annual precipitation is $<2 \mathrm{~mm}$, similar to the upper MDV, found that ${ }^{10} \mathrm{Be}_{\text {met }}$ was not translocated in soils under modern conditions, but during wetter El Niño events, translocation was possible, when precipitation was 4.6 times greater ${ }^{35}$. By analogy, the lack of evidence for ${ }^{10} \mathrm{Be}_{\text {met }}$ translocation in the near-surface soils in the stable upland sites suggests that precipitation has been $<\sim 10 \mathrm{~mm}$ swe since $\sim 6.0 \mathrm{Ma}$; a value similar to contemporary precipitations. However, water may infiltrate the soils without ${ }^{10} \mathrm{Be}_{\mathrm{met}}$ translocation. In fact, in places where the ground surface warms above $0^{\circ} \mathrm{C}$ for a few hours such as in University Valley, snowmelt was observed to infiltrate the dry permafrost and reach the shallow ice table ${ }^{15}$. Further evidence of snowmelt infiltrating and freezing at some depth in the soils comes from the $\delta^{18} \mathrm{O}$ and D-excess profiles of the near-surface ground ice at University 
Valley, Friis Hills and Table Mountain ${ }^{14-16}$. The $\delta^{18} \mathrm{O}$ profiles of ground ice at the three sites are very similar, which suggest that the near-surface icy permafrost is dynamic and responds synchronously to the late Quaternary climatic changes ${ }^{14-16}$. Therefore, infiltrating snowmelt is occurring during contemporary times and contributes to developing the ground ice; however, the amount of precipitation, or snowmelt, has been insufficient (likely $<10 \mathrm{~mm}$ swe) to translocate ${ }^{10} \mathrm{Be}_{\text {met }}$ in the dry permafrost soils since $6.0 \mathrm{Ma}$.

\section{Paleoclimate reconstruction during the late Miocene}

The presence of ${ }^{10} \mathrm{Be}_{\mathrm{met}}$ and the profile inflection at $227 \mathrm{~cm}$ at Friis Hills and $349 \mathrm{~cm}$ at Table Mountain suggest that the sites had an active layer with enough precipitation for the translocation clays in the soils until $\sim 6.0$ Ma. Considering that the translocation of clays does not occur in permafrost, we assume that the profile inflection depths represent the thickness of the active layer at 6.0 Ma. By correcting for the vertical erosion since $6.0 \mathrm{Ma}$, calculated from erosion rates at each sites ( $\sim 57 \mathrm{~cm}$ at Friis Hills and $\sim 7 \mathrm{~cm}$ at Table Mountain) and removing the volume added by the growth of excess ice in the permafrost $(\sim 10 \mathrm{~cm} \text { at both sites })^{36}$, the maximum active layer thickness was $274 \mathrm{~cm}$ at Friis Hills and $345 \mathrm{~cm}$ at Table Mountain at 6.0 Ma. Currently, active layer thicknesses range from $\sim 1 \mathrm{~m}$ along the coastal regions to $\sim 5 \mathrm{~cm}$ in the upper elevations ${ }^{37}$, and a strong relation exists between active layer thickness and the mean annual air temperature (MAAT; $y=13,077 \mathrm{e}^{0.3052 \mathrm{x}} ; \mathrm{r}^{2}=0.80$ ), and mean summer air temperature $\left(\right.$ MSAT; $\left.y=98.925 \mathrm{e}^{0.1952 x} ; \mathrm{r}^{2}=0.72\right)$.

The PERICLIMv.1.0 model ${ }^{38}$, which includes thawed ground thermal conductivity, soil moisture and thawing n-factor as parameters, was used to estimate air temperatures based on the 
active layer thickness through inverse solution of the Stefan equation (Fig. S4 and Table S4) ${ }^{38}$. The PERICLIM model was first able to reproduce the modern active layer thickness in the MDV solely by varying the annual air temperature amplitude, with values of ground thermal parameters typical of nearly dry soils and kept constant between the sites (Fig. S4). To estimate air temperatures during the late Miocene, the ground thermal parameters were adjusted for typical near-saturated active layer with fine sand soils and considering that there is no evidence of vegetation at these sites since the mid-Miocene ${ }^{39}$, the value of the thawing $\mathrm{n}$-factor was set to representative of a surface with no organic layer or vegetation cover. Based on the paleo-active layer thickness estimated from $\left[{ }^{10} \mathrm{Be}\right.$ met $](274 \mathrm{~cm}$ at Friis Hills and $345 \mathrm{~cm}$ at Table Mountain), the PERICLIM model predicts a MAAT ranging between -11 and $-8^{\circ} \mathrm{C}$ and a MSAT in the 7 to $10^{\circ} \mathrm{C}$ range, which are much warmer than the modern MAAT and MSAT of $-22^{\circ} \mathrm{C}$ and $-13^{\circ} \mathrm{C}$, respectively ${ }^{40}$. These reconstructed air temperatures and active layer thickness at $\sim 6.0 \mathrm{Ma}$ for the stable upland zone of the MDV are comparable to modern environments in highland mid-Arctic, such as west Greenland ${ }^{41}$; although paleo-active layers at Friis Hills and Table Mountain are likely thicker due to absence of organic matter and vegetation cover.

Considering the lapse-rate, the paleo-air temperature reconstruction in the high elevations at $\sim 6.0$ $\mathrm{Ma}$ are in line with other regional proxies from the coastal regions and provide evidence that the late Miocene warm-wet interval(s) extended to the high elevations of the MDV with the onset of permanent polar aridity starting only at $\sim 6.0 \mathrm{Ma}$. For example, MSAT during the Neogene in lower Taylor Valley ( $80 \mathrm{~m}$ a.sl.; Fig. 1) were $\sim 5^{\circ} \mathrm{C}$ with a transition to cooler conditions occurring between 4.1 and 2.6 $\mathrm{Ma}^{42}$. A similar MSAT was reconstructed based on lipid biomarkers at Oliver Bluffs ( $850 \mathrm{~km}$ south of the MDV), which also allowed the existence of a 
low diversity tundra plant community ${ }^{43}$. At the continental-scale, long-term temperature records throughout the Neogene suggest summer temperatures ranged between 4 and $12{ }^{\circ} \mathrm{C}^{44}$. Evidence supporting a warm-wet late Miocene period and melting of glacial ice are found in various coastal regions, such as the Ross Embayment ${ }^{4}$, Prydz Bay ${ }^{45}$ and the Totten Glacier region ${ }^{46}$.

\section{Conclusion}

The timing of permanent polar aridity across the MDV is critical to our understanding of the overall response of glacial systems in Antarctica, including the EAIS. Although proxy data show surface temperatures remained significantly warmer through the late Miocene than today ${ }^{47-49}$, the hypothesis that the upper elevations remained under a hyper-arid polar climate since the MMCT has persisted. This study analyzed ${ }^{10} \mathrm{Be}_{\text {met }}$ from more than 64 samples collected at three locations in the upper MDV and 10 different boreholes, using two chemical protocols and two different AMS laboratories. The results suggest that ${ }^{10} \mathrm{Be}_{\text {met }}$ infiltrated the ground for a period between the mid-Miocene and 6.0 Ma, which supports the presence of liquid water post-MMCT with the onset of polar aridity starting near 6.0 Ma. This new finding provides strong evidence that the climatic conditions have not remained stable since the MMCT, and corroborates regional evidence which suggests that the Antarctic Ice Sheet became larger, drier, and less dynamic during the late Miocene ${ }^{50}$. The onset of permanent polar aridity in the high elevation of the MDV during the late Miocene coincides with a 2 to $3{ }^{\circ} \mathrm{C}$ decrease in ocean surface temperatures in the Southern Ocean between 7 and $5.4 \mathrm{Ma}^{47}$ (Fig. 1). This late Miocene cooling is also synchronous with late Miocene aridity and terrestrial ecosystem changes with increasing meridional temperature gradients ${ }^{51,52}$. Most importantly, this finding implies that the MDV are not a landscape frozen in time and they may be more susceptible to climate change than anticipated. 


\section{Acknowledgements}

The Friis Hills Drilling Project (austral summer 2016 - 17) was funded by the Past Antarctic Climate Programme. The sampling at University Valley was funded by NASA-ASTEP grant to C. McKay. Fieldwork at Friis Hills and Table Mountain was made possible with the logistical support of Antarctica New Zealand. We would like to thank A. Pyne, R. Pyne, H. Chorley and Webster Drilling for retrieving the cores at Friis Hills. A special thank you to N. Bertler for allowing us to use the GNS Ice Core Facility to store and sample the permafrost cores. Laboratory work was made possible with the help of the technical staff at the Cosmogenic Nuclide Laboratory at the Victoria University of Wellington (L. Ashworth) and the Laboratory of Ion Beam Physics at ETH, Zürich (P. Gautschi). AMS Analysis was in part funded an Antarctic Science International Bursary.

\section{Author Contributions}

M. V., W. D., K. N., and D. L. designed this project, contributed to data analysis/interpretation and writing the manuscript. C. T.-L. analyzed the preliminary samples from Friis Hills (FA, C1 and C2) and University Valley. M. C. ran the ${ }^{10} \mathrm{Be}_{\text {met }}$ samples including AMS data reduction. R. L. and T. N. developed the Friis Hills Drilling Project. All authors edited the whole manuscript.

\section{Competing Interest Statement}

The authors declare no competing interests. 


\section{Figures}

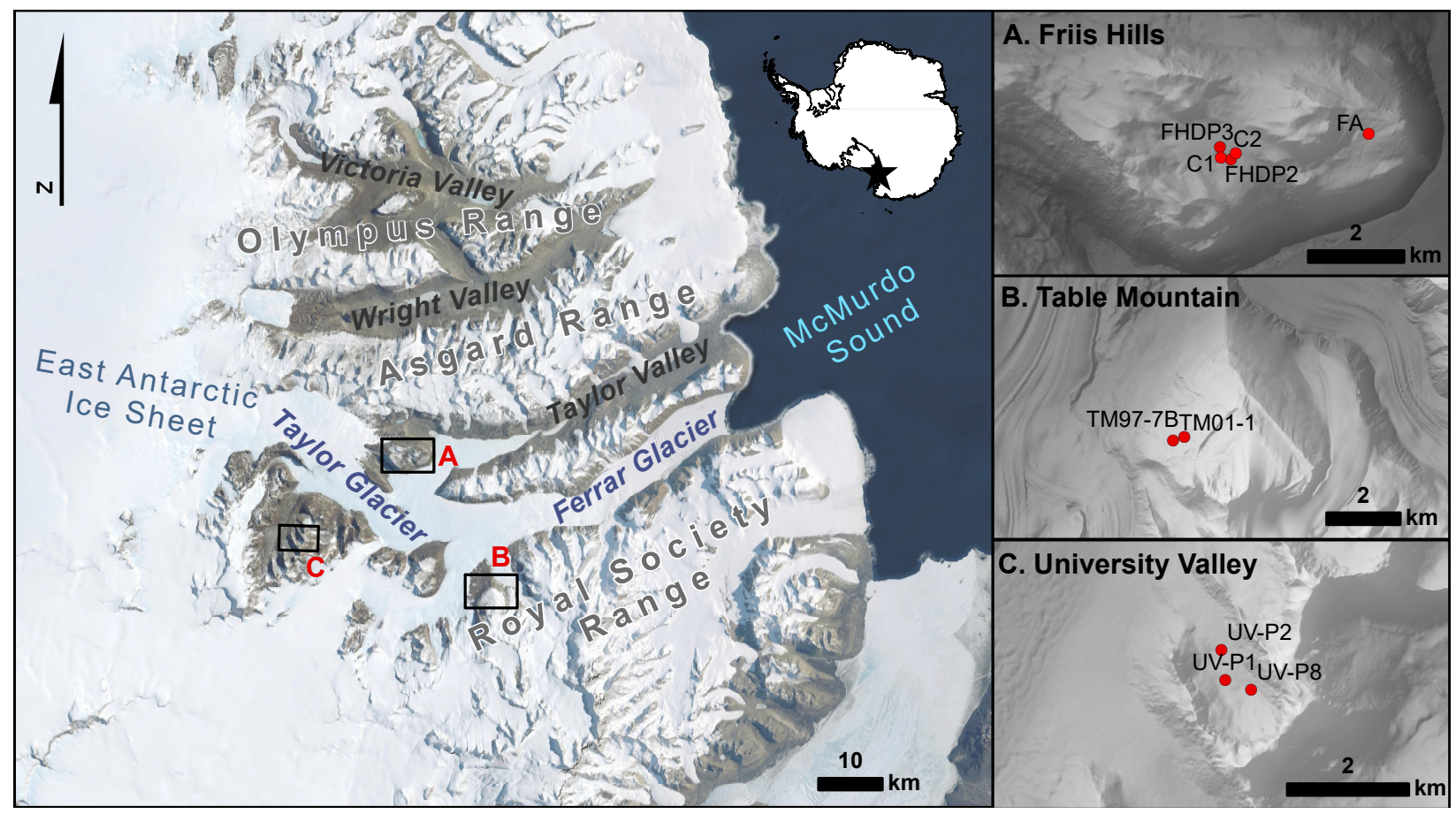

Fig 1: Location of boreholes at Friis Hills, Table Mountain and University Valley in the McMurdo Dry Valleys of Antarctica. 


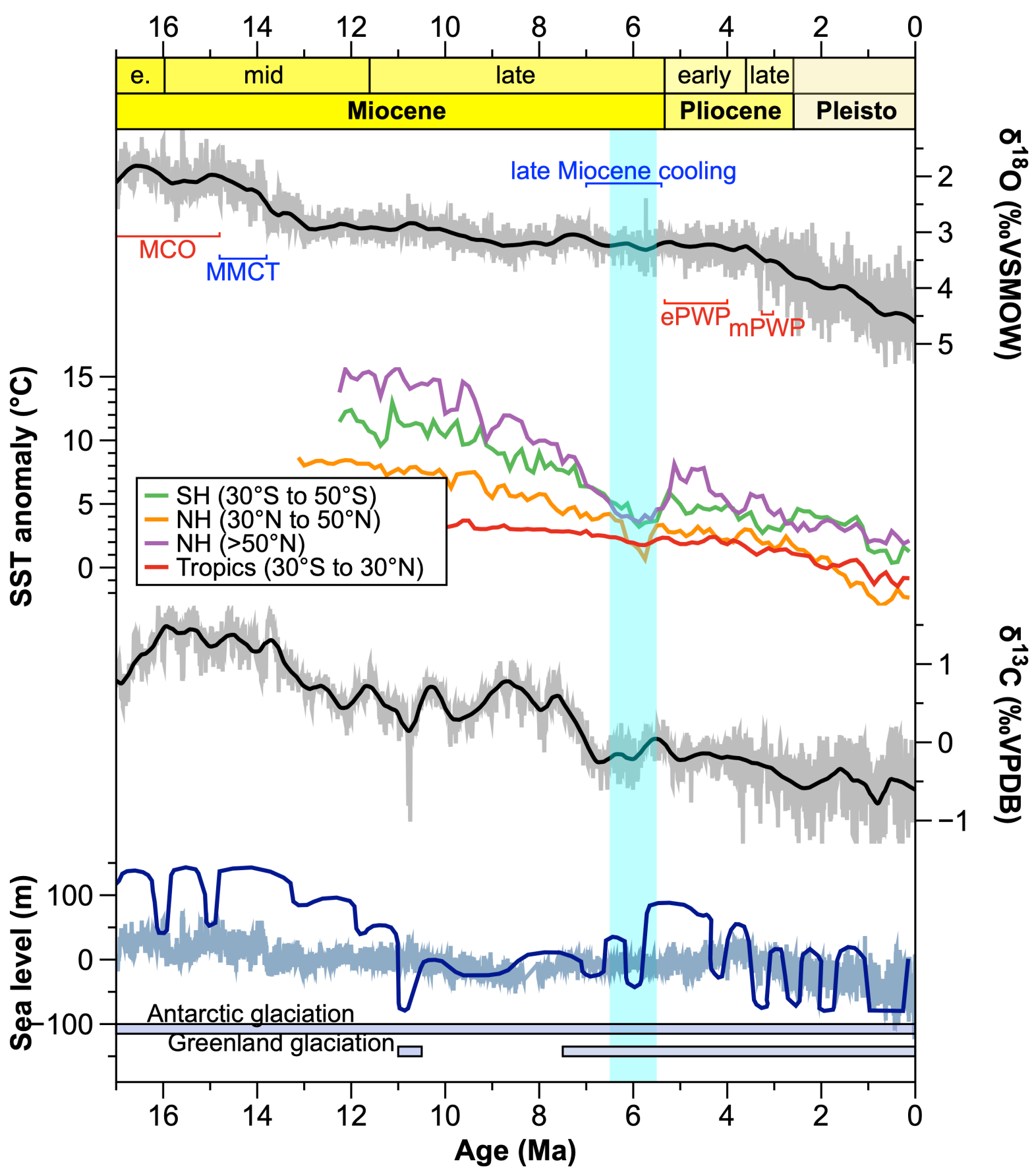

Fig 2: Compiled global and regional paleoclimatic indicators of the past $17 \mathrm{Ma}$ : benthic foraminifera $\delta^{18} \mathrm{O}$ with moving average in black ${ }^{53}$, regional sea surface temperature (SST) anomalies ${ }^{47}$, benthic foraminifera $\delta^{13} \mathrm{C}$ with moving average in black ${ }^{53}$, global mean sea level estimates in dark blue ${ }^{54}$ and light blue ${ }^{55}$. Major warming events (red brackets), major cooling event (blue bracket) are labelled, and Greenland ${ }^{56}$ and Antarctic ${ }^{1}$ glaciations are labelled. Onset of permanent polar aridity in East Antarctica based on this study is indicated with teal panel. 

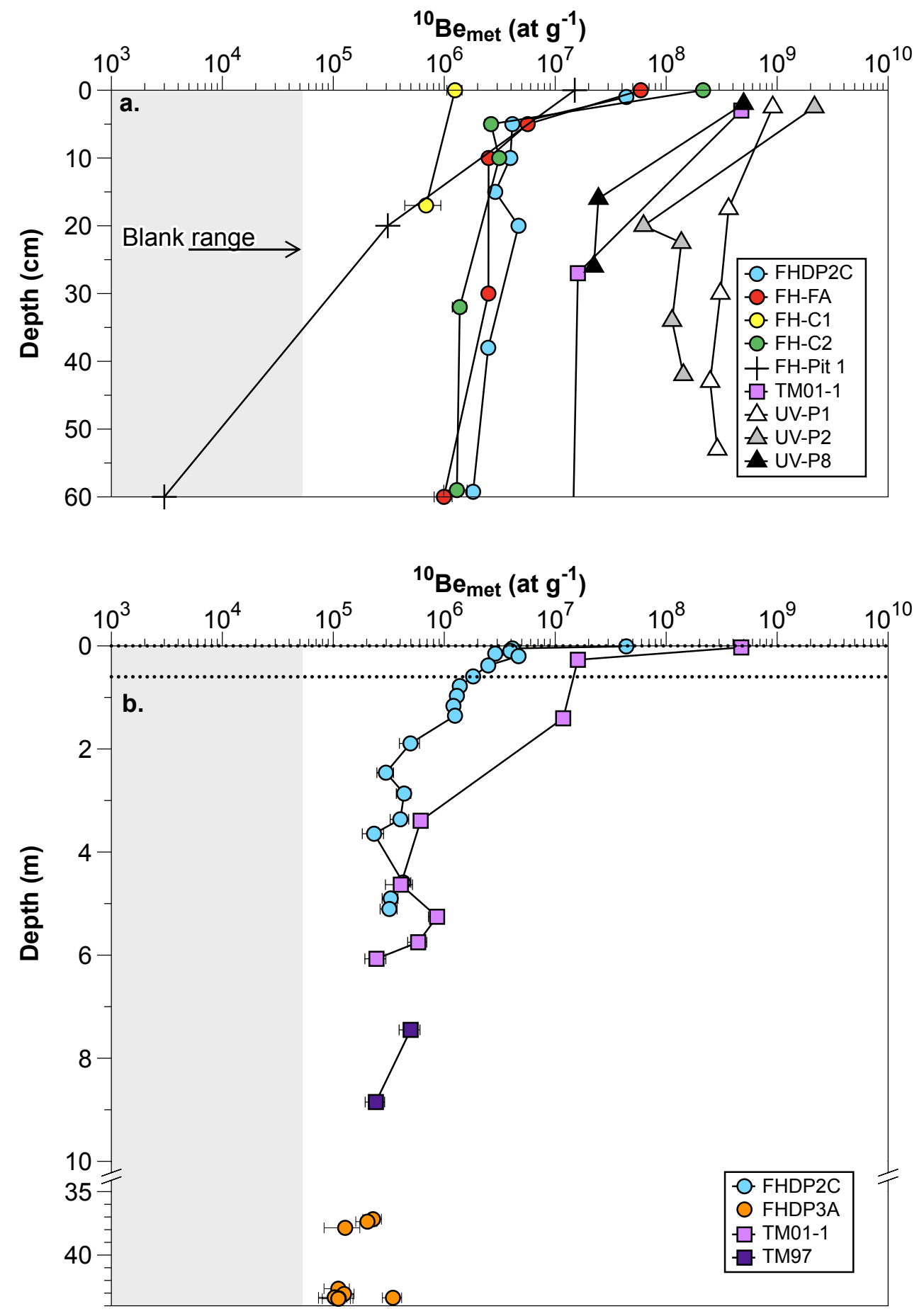

Fig. 3: ${ }^{10} \mathrm{Be}_{\mathrm{met}}$ concentrations profiles in high elevation sites of the McMurdo Dry Valleys. a. ${ }^{10} \mathrm{Be}_{\mathrm{met}}$ concentrations measured at shallow depths at Friis Hills, Table Mountain (TM01-1 reruns) and University Valley compared to original Table Mountain dataset ${ }^{6}$ and Friis Hills Pit $1^{3}$. b. ${ }^{10} \mathrm{Be}_{\text {met }}$ concentrations measured in both shallow and deep Miocene sites. FHDP2C and FHDP3A from Friis Hills and TM01 and TM97 from Table Mountain. Dotted line represents the depth of panel a. 


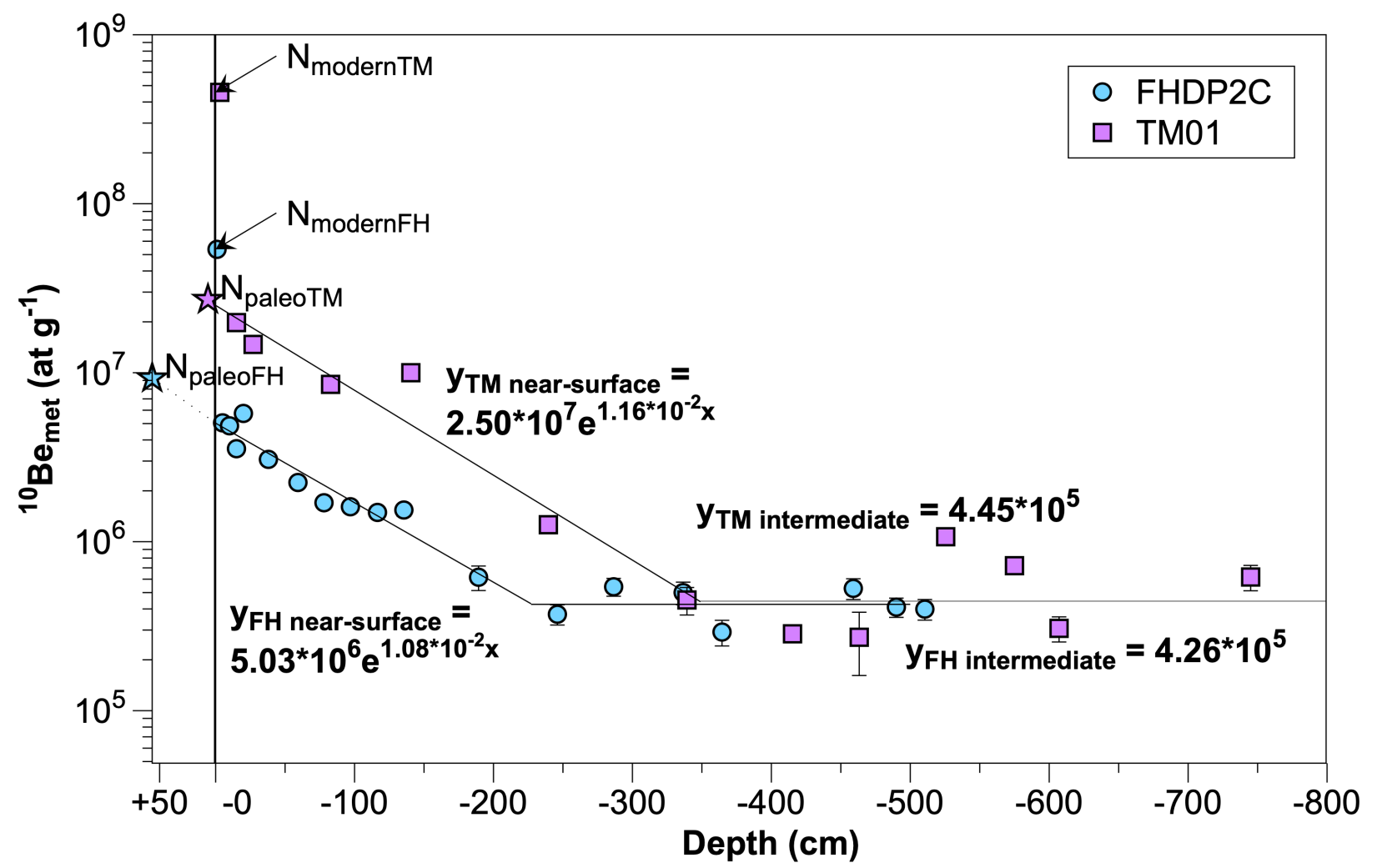

Fig. 4: Exponential regression equations for measured ${ }^{10} \mathrm{Be}_{\text {met }}$ concentrations of FHDP2C and TM01-1 and TM97 in sub-surface profiles for upper and intermediate sample groups. Segmentation at $227 \mathrm{~cm}$ depth in Friis Hills samples and $349 \mathrm{~cm}$ depth in Table Mountain samples. 


\section{References}

1 Coxall, H. K., Wilson, P. A., Pälike, H., Lear, C. H. \& Backman, J. Rapid stepwise onset of Antarctic glaciation and deeper calcite compensation in the Pacific Ocean. Nature 433, 53-57 (2005).

2 Denton, G. H., Sugden, D. E., Marchant, D., Hall, B. L. \& Wilch, T. I. East Antarctic Ice Sheet sensitivity to Pliocene climatic change from a Dry Valleys perspective. Geografiska Annaler: $\quad$ Series A, Physical Geography 75, 155-204, doi:10.1080/04353676.1993.11880393 (1993).

3 Valletta, R. D., Willenbring, J. K., Lewis, A. R., Ashworth, A. C. \& Caffee, M. Extreme decay of meteoric beryllium-10 as a proxy for persistent aridity. Scientific reports $\mathbf{5}, 17813$, doi:10.1038/srep17813 (2015).

4 McKay, R. et al. The stratigraphic signature of the late Cenozoic Antarctic Ice Sheets in the Ross Embayment. Geological Society of America Bulletin 121, 1537-1561 (2009).

5 Schiller, M., Dickinson, W., Ditchburn, R., Graham, I. \& Zondervan, A. Atmospheric 10Be in an Antarctic soil: Implications for climate change. Journal of Geophysical Research: Earth Surface 114 (2009).

6 Dickinson, W. W., Schiller, M., Ditchburn, B. G., Graham, I. J. \& Zondervan, A. Meteoric Be-10 from Sirius Group suggests high elevation McMurdo Dry Valleys permanently frozen since 6 Ma. Earth and Planetary Science Letters 355, 13-19, doi:10.6073/pasta/9dda244e95ce8dfcdbd9b94d2289ef1d (2012).

$7 \quad$ McHargue, L. \& Damon, P. The global beryllium 10 cycle. Reviews of Geophysics 29, 141158 (1991).

8 Willenbring, J. K. \& von Blanckenburg, F. Meteoric cosmogenic Beryllium-10 adsorbed to river sediment and soil: Applications for Earth-surface dynamics. Earth-Science Reviews 98, 105-122 (2010).

9 Marchant, D. \& Head III, J. W. Antarctic dry valleys: Microclimate zonation, variable geomorphic processes, and implications for assessing climate change on Mars. Icarus 192, 187-222, doi:10.1016/j.icarus.2007.06.018 (2007).

10 Sugden, D. E. et al. Preservation of Miocene glacier ice in East Antarctica. Nature 376, 412-414, doi:10.1038/376412a0 (1995).

11 Summerfield, M. et al. Long-term rates of denudation in the Dry Valleys, Transantarctic Mountains, southern Victoria Land, Antarctica based on in-situ-produced cosmogenic 21Ne. Geomorphology 27, 113-129, doi:10.1016/S0169-555X(98)00093-2 (1999).

12 Hindmarsh, R., Van der Wateren, F. \& Verbers, A. L. Sublimation of ice through sediment in Beacon Valley, Antarctica. Geografiska Annaler: Series A, Physical Geography 80, 209219 (1998).

13 Schorghofer, N. \& Aharonson, O. Stability and exchange of subsurface ice on Mars. Journal of Geophysical Research: Planets 110 (2005).

14 Dickinson, W. W. \& Rosen, M. R. Antarctic permafrost: An analogue for water and diagenetic minerals on Mars. Geology 31, 199-202, doi:10.1130/00917613(2003)031<0199:APAAFW>2.0.CO;2 (2003).

15 Lacelle, D. et al. Excess ground ice of condensation-diffusion origin in University Valley, Dry Valleys of Antarctica: evidence from isotope geochemistry and numerical modeling. Geochimica et Cosmochimica Acta 120, 280-297, doi:10.1016/j.gca.2013.06.032 (2013).

16 Verret, M. et al. Cryostratigraphy of mid-Miocene permafrost at Friis Hills, McMurdo Dry Valleys of Antarctica. Antarctic Science, 1-15 (2020). 
17 Fountain, A., Nylen, T. H., Monaghan, A., Basagic, H. J. \& Bromwich, D. Snow in the McMurdo dry valleys, Antarctica. International Journal of Climatology: A Journal of the Royal Meteorological Society 30, 633-642 (2010).

18 Lewis, A. R. \& Ashworth, A. C. An early to middle Miocene record of ice-sheet and landscape evolution from the Friis Hills, Antarctica. Bulletin 128, 719-738, doi:10.1130/B31319.1 (2015).

19 Chorley, H. et al. Antarctic Ice Sheet evolution and variability during the mid-Miocene Climate Transition ( 15.1-13.8 Ma), from the Friis Hills, Antarctica. Geological Society of America Bulletin (in review).

20 Miller, K. G. et al. The Phanerozoic record of global sea-level change. science 310, 12931298, doi:10.1126/science.1116412 (2005).

21 Zachos, J. C., Dickens, G. R. \& Zeebe, R. E. An early Cenozoic perspective on greenhouse warming and carbon-cycle dynamics. Nature 451, 279-283, doi:10.1038/nature06588 (2008).

22 Levy, R. et al. Antarctic ice sheet sensitivity to atmospheric CO2 variations in the early to mid-Miocene. Proceedings of the National Academy of Sciences 113, 3453-3458, doi:10.1073/pnas.1516030113 (2016).

23 Goff, J. R., Jennings, I. W. \& Dickinson, W. W. Depositional environment of Sirius Group sediments, Table mountain, dry Valleys area, Antarctica. Geografiska Annaler: Series A, Physical Geography 84, 11-24 (2002).

24 Barrett, P. \& Powell, R. Middle Cenozoic glacial beds at Table Mountain, southern Victoria land. Antarctic geoscience, 1059-1067 (1982).

25 Marchant, D., Denton, G., Swisher III, C. C. \& Potter Jr, N. Late Cenozoic Antarctic paleoclimate reconstructed from volcanic ashes in the Dry Valleys region of southern Victoria Land. Geological Society of America Bulletin 108, 181-194 (1996).

26 Ivy-Ochs, S., Schlüchter, C., Kubik, P. W., Dittrich-Hannen, B. \& Beer, J. r. Minimum 10Be exposure ages of early Pliocene for the Table Mountain plateau and the Sirius Group at Mount Fleming, dry valleys, Antarctica. Geology 23, 1007-1010 (1995).

27 Trinh-Le, C. A. Dry sedimentation processes in the high-elevation McMurdo Dry Valleys, Antarctica: A case study in University Valley MSc Thesis thesis, Victoria University of Wellington, (2017).

28 Lacelle, D. et al. Solar radiation and air and ground temperature relations in the cold and hyper-arid Quartermain Mountains, McMurdo Dry Valleys of Antarctica. Permafrost and Periglacial Processes 27, 163-176, doi:10.1002/ppp.1859 (2016).

29 Takahashi, Y., Minai, Y., Ambe, S., Makide, Y. \& Ambe, F. Comparison of adsorption behavior of multiple inorganic ions on kaolinite and silica in the presence of humic acid using the multitracer technique. Geochimica et Cosmochimica Acta 63, 815-836 (1999).

30 Campbell, I. \& Claridge, G. Antarctica: soils, weathering processes and environment. (Elsevier, 1987).

31 Delmas, R. J., Legrand, M., Aristarain, A. J. \& Zanolini, F. Volcanic deposits in Antarctic snow and ice. Journal of Geophysical Research: Atmospheres 90, 12901-12920 (1985).

32 Fisher, D. A., Lacelle, D., Pollard, W. \& Faucher, B. A model for stable isotopes of residual liquid water and ground ice in permafrost soils using arbitrary water chemistries and soilspecific empirical residual water functions. Permafrost and Periglacial Processes (2020).

33 Spector, P. \& Balco, G. Exposure-age data from across Antarctica reveal mid-Miocene establishment of polar desert climate. Geology 49, 91-95 (2021). 
34 Shang, J., Flury, M., Chen, G. \& Zhuang, J. Impact of flow rate, water content, and capillary forces on in situ colloid mobilization during infiltration in unsaturated sediments. Water Resources Research 44 (2008).

35 Wang, F. et al. Beryllium-10 concentrations in the hyper-arid soils in the Atacama Desert, Chile: Implications for arid soil formation rates and El Niño driven changes in Pliocene precipitation. Geochimica et Cosmochimica Acta 160, 227-242 (2015).

36 Burn, C. R. Cryostratigraphy, paleogeography, and climate change during the early Holocene warm interval, western Arctic coast, Canada. Canadian Journal of Earth Sciences 34, 912-925 (1997).

37 Adlam, L. S., Balks, M. R., Seybold, C. A. \& Campbell, D. I. in Annual Antarctic Conference. 45-52 (Cambridge University Press).

38 Uxa, T., Kř́žžek, M. \& Hrbáček, F. PERICLIMv1. 0: A model deriving palaeo-air temperatures from thaw depth in past permafrost regions. Geoscientific Model Development Discussions, 1-22 (2020).

39 Lewis, A. et al. Mid-Miocene cooling and the extinction of tundra in continental Antarctica. Proceedings of the National Academy of Sciences 105, 10676-10680, doi:10.1073/pnas.0802501105 (2008).

40 Fountain, A. \& Doran, P. McMurdo Dry Valleys Friis Hills Meteorological Station Daily Averages. doi:10.6073/pasta/9dda244e95ce8dfcdbd9b94d2289ef1d (2016).

41 Van Tatenhove, F. G. \& Olesen, O. B. Ground temperature and related permafrost characteristics in West Greenland. Permafrost and Periglacial Processes 5, 199-215 (1994).

42 Ohneiser, C. et al. Warm fjords and vegetated landscapes in early Pliocene East Antarctica. Earth and Planetary Science Letters 534, 116045 (2020).

43 Rees-Owen, R. L. et al. The last forests on Antarctica: reconstructing flora and temperature from the Neogene Sirius Group, Transantarctic Mountains. Organic Geochemistry 118, 414 (2018).

44 Warny, S. et al. Palynomorphs from a sediment core reveal a sudden remarkably warm Antarctica during the middle Miocene. Geology 37, 955-958, doi:10.1130/G30139A.1 (2009).

45 Hambrey, M. J. \& McKelvey, B. Major Neogene fluctuations of the East Antarctic ice sheet: Stratigraphic evidence from the Lambert Glacier region. Geology 28, 887-890, doi:10.1130/0091-7613(2000)28<887:MNFOTE>2.0.CO;2 (2000).

46 Gulick, S. P. et al. Initiation and long-term instability of the East Antarctic Ice Sheet. Nature 552, 225-229 (2017).

47 Herbert, T. D. et al. Late Miocene global cooling and the rise of modern ecosystems. Nature Geoscience 9, 843-847 (2016).

48 Prebble, J. G. et al. Terrestrial climate evolution in the Southwest Pacific over the past 30 million years. Earth and Planetary Science Letters 459, 136-144 (2017).

49 Super, J. R. et al. Miocene evolution of North Atlantic Sea surface temperature. Paleoceanography and Paleoclimatology 35, e2019PA003748 (2020).

50 Shakun, J. D. et al. Minimal East Antarctic Ice Sheet retreat onto land during the past eight million years. Nature 558, 284-287 (2018).

51 Schuster, M. et al. The age of the Sahara desert. Science 311, 821-821 (2006). 
52 Amidon, W. H. et al. Mio-Pliocene aridity in the south-central Andes associated with Southern Hemisphere cold periods. Proceedings of the National Academy of Sciences 114, 6474-6479 (2017).

53 Westerhold, T. et al. An astronomically dated record of Earth's climate and its predictability over the last 66 million years. Science 369, 1383-1387 (2020).

54 Miller, K. et al. The Phanerozoic record of global sea-level change. science 310, 12931298, doi:10.1126/science.1116412 (2005).

55 Miller, K. G. et al. Cenozoic sea-level and cryospheric evolution from deep-sea geochemical and continental margin records. Science advances 6, eaaz1346 (2020).

56 Bierman, P. R., Shakun, J. D., Corbett, L. B., Zimmerman, S. R. \& Rood, D. H. A persistent and dynamic East Greenland Ice Sheet over the past 7.5 million years. Nature 540, 256260 (2016). 


\section{Methods}

\section{Field seasons and sample preparation}

Table Mountain samples were collected from cores drilled during the 1996-97 (TM97-7B) and 2000-01 (TM01-1) field seasons led by researchers of the Victoria University of Wellington and logistical support from Antarctica New Zealand. University Valley cores (UV-P1, P2 and P8) were drilled in polygonal ground in January 2013 by researchers from the NASA Ames Research Center and the University of Ottawa. In December 2014, three preliminary cores were collected for a ${ }^{10} \mathrm{Be}_{\text {met }}$ survey at Friis Hills. Additional samples were also selected from cores of the 2016 Friis Hills Drilling Project (FHDP2C and FHDP3A) led by researchers of the Victoria University of Wellington. The samples selected were the following: 8 samples from TM01-1 $(0-6 \mathrm{~m}$ depth), 2 samples from core TM97-7B (7 - $9 \mathrm{~m}$ depth), 13 samples from the University Valley cores (P1, P2 and P8; $<50 \mathrm{~cm}$ depth), 12 samples from the Friis Hills preliminary cores (C1, C2 and FA; $<60 \mathrm{~cm}), 19$ samples from FHDP2C ( $0-5 \mathrm{~m}$ depth) and 10 samples from FHDP3A (37 - $44 \mathrm{~m}$ depth) for a total of 64 samples. All sediment samples were manually dry-sieved to $45-$ $90 \mu \mathrm{m}$ and precisely weighted between $0.75-1.00 \mathrm{~g}$ into $50 \mathrm{ml}$ centrifuge tubes before undergoing the sequential extraction procedure.

\section{Sequential ${ }^{10} \mathrm{Be}_{\text {met }}$ extraction, column chemistry, precipitation, oxydation and target packing}

The method used in this paper follows the extraction method described in Wittman et al. ${ }^{1}$ (adapted from ${ }^{2-4}$ ). Amorphous oxide-bound Beryllium (Be $\mathrm{e}_{\mathrm{am}-\mathrm{ox}}$ ) was first extracted by adding 10 $\mathrm{ml}$ of $0.5 \mathrm{M} \mathrm{HCl}$ and gently shaking at room temperature for $24 \mathrm{~h}$. The crystalline oxide-bound Beryllium $\left(\mathrm{Be}_{\mathrm{x}-\mathrm{ox}}\right)$ was secondly extracted by adding $10 \mathrm{ml}$ of $1 \mathrm{M}$ hydroxylamine-hydrochloride 
solution (in $1 \mathrm{M} \mathrm{HCl}$ ) and placing the samples in an ultrasonic bath at $80^{\circ} \mathrm{C}$ for $4 \mathrm{~h}$, shaking occasionally. Hydroxylamine-hydrochloride removal was done by a series of $10 \mathrm{ml}$ concentrated $\mathrm{HNO}_{3}$ and $10 \mathrm{ml} 30 \% \mathrm{H}_{2} \mathrm{O}_{2}$ washes. The solution with both $\mathrm{Be}_{\mathrm{am}-\mathrm{ox}}$ and $\mathrm{B}_{\text {ex-ox }}$ leachates was dried and then dissolved in $10 \mathrm{ml} 3 \mathrm{M} \mathrm{HNO}_{3}$. A $0.5 \mathrm{ml}$ sub-sample was retrieved for aliquots of major and minor element analysis and for ${ }^{9} \mathrm{Be}$ measurement. A ${ }^{9} \mathrm{Be}$ carrier solution of $\sim 0.9 \mathrm{~g}$ ( $305 \mathrm{ppm}$ in $3 \mathrm{M} \mathrm{HNO}_{3}$ ) was added to the solution which was passed through Fe columns ( $2 \mathrm{ml}$

Biorad 1-X8 100-200 mesh anion resin in $15 \mathrm{ml}$ Eichrom columns) and Be columns (5 ml Biorad AG50-X8 200-400 mesh cation resin in $15 \mathrm{ml}$ Eichrom columns).

To precipitate $\mathrm{Be}(\mathrm{OH})_{2}, 0.550 \mathrm{ml}$ of concentrated $(25 \%) \mathrm{NH}_{4} \mathrm{OH}$ were added to the samples taken up in $5 \mathrm{ml} 1 \mathrm{M} \mathrm{HNO}_{3}$ (to reach a $\mathrm{pH} \sim 9$ ). The samples were centrifuged, decanted and the precipitates were redissolved in $5 \mathrm{ml} 1 \mathrm{M} \mathrm{HNO}_{3}$. This step was repeated a second time and a final $3 \mathrm{ml}$ milliQ $\mathrm{H}_{2} \mathrm{O}$ wash was performed to remove ammonia from the $\mathrm{Be}(\mathrm{OH})_{2}$ precipitates. The $\mathrm{Be}(\mathrm{OH})_{2}$ precipitates were then dissolved in $0.3 \mathrm{ml}$ of $5 \mathrm{M} \mathrm{HNO}_{3}$, transferred to quartz crucibles and dried down at $120^{\circ} \mathrm{C}$. The samples were subsequently calcined for $1-2$ minutes over open flame to form BeO. Niobium ( $\sim 3 \mathrm{mg}$ ) was incorporated to form a homogeneous powder. The powder was then transferred into accelerator mass spectrometer (AMS) aluminum targets.

\section{AMS measurement and sample calibration}

Samples from preliminary cores FA, C1 and C2 and University Valley were measured on the 500 kV AMS (TANDY, ETH Zürich, 2017-18) while FHDP2C, FHDP3A, TM01 and TM97 samples were measured on the $300 \mathrm{kV}$ AMS (MILEA, ETH Zürich, 2019). The measured ${ }^{10} \mathrm{Be} /{ }^{9} \mathrm{Be}$ ratios 
were normalized using the $2007 \mathrm{~S}$ and S2010N standards ${ }^{5}$. The concentration of ${ }^{10} \mathrm{Be}_{\text {met }}\left(\right.$ at $\left.\mathrm{g}^{-1}\right)$ per samples was determined with the following equation:

$$
\text { [1] } C^{10} B e_{\mathrm{met}}=\frac{\left(\frac{N_{0} \cdot m_{9} B e \text { carrier }}{M\left({ }^{\circ} B e\right)}\right) \cdot\left(\frac{{ }^{10} B e_{\mathrm{met}}}{{ }^{9} B e}\right)_{\text {measured }}{ }^{-10 B e_{\mathrm{met}} \text { blank }}}{m_{\text {sample }}}
$$

where $\left({ }^{10} \mathrm{Be} \text { met } /{ }^{9} \mathrm{Be}\right)_{\text {measured }}$ is the measured and standard normalized ratio of ${ }^{10} \mathrm{Be}_{\text {met }}$ to ${ }^{9} \mathrm{Be}$ measured directly from the sample, $\mathrm{N}_{0}$ is Avogadro's number $\left(6.022 \times 10^{23} \mathrm{~mol}^{-1}\right) \mathrm{m}_{9 \mathrm{Be}}$ carrier is the mass of ${ }^{9} \mathrm{Be}$ in the added carrier solution $(\mathrm{g}), \mathrm{M}\left({ }^{9} \mathrm{Be}\right)$ is the molar mass of ${ }^{9} \mathrm{Be}\left(\mathrm{g} \mathrm{mol}^{-1}\right)$, ${ }^{10} \mathrm{Be}_{\text {met }}$ blank is the number of ${ }^{9} \mathrm{Be}$ atoms added by the carrier solution multiplied by the average ${ }^{10} \mathrm{Be} /{ }^{9} \mathrm{Be}$ ratio measured in laboratory blank samples (Tables $\mathrm{S} 1$ to $\mathrm{S} 3$ ). To ensure that ${ }^{10} \mathrm{Be}_{\text {met }}$ measurements were independent of grain-size distribution ${ }^{1}$, the stable isotope ${ }^{9} \mathrm{Be}$ was measured on the aliquot retrieved during the extraction process on an Agilent Microwave Plasma-Atomic Emission Spectrometry (MP-AES) instrument model 4210 (University of Canterbury, School of Physical and Chemical Sciences). Concentrations in ppm were measured with a standard error of $\pm 15 \%$. Concentrations of ${ }^{9} \mathrm{Be}$ measured independently on the MP-AES varied between $9.6 \times 10^{16}$ and $3.0 \times 10^{17}$ at $\mathrm{g}^{-1}$. When normalized to ${ }^{9} \mathrm{Be},{ }^{10} \mathrm{Be}$ met values were found to be highly correlated to non-normalized ${ }^{10} \mathrm{Be}_{\text {met }}$ values, implying that the reported ${ }^{10} \mathrm{Be}_{\text {met }}$ concentrations are not grainsize dependant (Fig. S1).

\section{Correction of Table Mountain samples and implications of leaching method}

The study of ${ }^{10} \mathrm{Be}_{\text {met }}$ at Table Mountain by Dickinson et al. along with other early ${ }^{10} \mathrm{Be}_{\text {met }}$ investigations in the MDV ${ }^{6-9}$ used a more aggressive leaching method to extract ${ }^{10} \mathrm{Be}_{\text {met }}$ from the sediment $\left(6 \mathrm{M} \mathrm{HCl} \text { for } 1 \mathrm{~h} \text { at } 100^{\circ} \mathrm{C}\right)^{10,11}$. This method was criticized because of the possibility of 
liberating in situ ${ }^{10} \mathrm{Be}$ via partial decomposition of clay minerals ${ }^{12}$. After correcting for in situ ${ }^{10} \mathrm{Be}$ contamination in Table Mountain samples, Valletta et al. suggested using the Wittmann et al. mild leaching method $(0.5 \mathrm{M} \mathrm{HCl}$ for $24 \mathrm{~h}$ at room temperature $+1 \mathrm{M}$ hydroxylamine hydrochloride for $4 \mathrm{~h}$ in a $80^{\circ} \mathrm{C}$ ultrasonic bath) ${ }^{1,12}$. This leaching protocol has shown to fully remove ${ }^{10} \mathrm{Be}_{\text {met }}$ and to release minimal in-situ ${ }^{10} \mathrm{Be}{ }^{1}$.

To test the possible contamination from the aggressive leaching method, five Table Mountain (TM01) samples were duplicated using the mild leaching method. ${ }^{10} \mathrm{Be}_{\text {met }}$ concentrations were 1.64 times higher using the mild leaching method than the values obtained using the aggressive method ${ }^{6}$ (Fig. S3). Therefore, the concerns raised by Valletta et al. about aggressive leaching and possible contamination from in situ ${ }^{10} \mathrm{Be}$, which would have increased the measured ${ }^{10} \mathrm{Be}_{\text {met }}$ concentrations, were not applicable ${ }^{12}$. The discrepancy found from the method testing could be due to a combination of two main causes: (1) the leaching process and/or (2) the AMS measurement and sample calibration. The Table Mountain samples were originally analyzed at the AMS facility at GNS Science, New Zealand and calibrated with the National Institute of Standards and Technology (NIST) standard SRM $4325^{5,6,13}$. The different mass spectrometers used for each study along with natural variance could explain $10 \%$ difference at most ${ }^{14}$. Therefore, the larger (64\%) difference requires another explanation. The aggressive $\mathrm{HCl}$ leach did not include a step to leach the $\mathrm{Be}_{\mathrm{ex}-\mathrm{ox}}$, of which Wittmann et al. calculated that 20 to $45 \%$ of the total ${ }^{10} \mathrm{Be}_{\text {met }}$ was located in this fraction ${ }^{1}$. It is still unclear why higher concentrations were measured using the mild leach, but we hypothesize that the $\mathrm{Be}_{\mathrm{ex}-\mathrm{ox}}$ was not fully extracted by the aggressive $\mathrm{HCl}$ leach. $\mathrm{HCl}$ dissolves the most labile soil Beryllium phases (poorly-crystalline beryllium oxides). More complex beryllium oxides need to be leached by reductive dissolution at 
acidic $\mathrm{pH}$, which also prevents re-precipitation. This could therefore explain how the original Table Mountain samples had lower concentrations of ${ }^{10} \mathrm{Be}_{\text {met. }}$ However, the risks of contamination using the aggressive method may not fully be ruled out and to limit uncertainty, using the Wittmann et al. method for all subsequent ${ }^{10} \mathrm{Be}_{\text {met }}$ leaching is recommended ${ }^{1}$. Although the discrepancy in method needs further research, considering the offsets were consistent through all samples because the leaches came from the same parent material and were within the same grain-size range, the offset was applied as a correction factor to all Table Mountain samples (Fig. S2).

\section{Closure ages using paleo-surface concentrations of ${ }^{10} \mathrm{Be}_{\text {met }}$}

Here we use the two Miocene-age $\left[{ }^{10} \mathrm{Be}\right.$ met $]$ profiles to solve for one common variable: closure age (i.e. time when ${ }^{10} \mathrm{Be}_{\text {met }}$ stopped infiltrating the ground and was sealed-off in the sediment profile; Fig. S3). The regional proximity and the similar cryostratigraphic profiles of Friis Hills and Table Mountain allow two important assumptions to calculate closure ages of the soil profiles: (1) the flux of ${ }^{10} \mathrm{Be}_{\text {met }}$ is comparable at both sites and (2) ${ }^{10} \mathrm{Be}$ met stopped migrating in the soil profiles at the same time (i.e. the closure age is synchronous). These assumptions allow us to compare erosion rates at the two different sites. Dickinson et al. established that time since closure ages (yr) could be calculated using $\left[{ }^{10} \mathrm{Be}_{\mathrm{met}}\right]$ of the paleo-surface ${ }^{6}$ :

$$
\text { [2] } t=\frac{-\ln \frac{N_{\text {paleo }}}{N_{\text {moder } n}}}{\lambda}
$$


where $\mathrm{N}_{\text {paleo }}$ is the paleo-surface concentration of ${ }^{10} \mathrm{Be}_{\text {met }}\left(\right.$ at $\mathrm{g}^{-1}$ ) and $\mathrm{N}_{\text {modern }}$ is the modern surface concentration of ${ }^{10} \mathrm{Be}_{\text {met }}\left(\mathrm{at}^{-1}\right)$. $\mathrm{N}_{\text {paleo }}$ can be projected by fitting an exponential equation:

$$
\text { [3] } N_{\text {paleo }}=a e^{b E}
$$

where $\mathrm{a}$ and $\mathrm{b}$ are regression constants and $\mathrm{E}$ is a length measurement (multiplied by time) of the erosion rate $\varepsilon$ described by the following equation:

$$
[4] \varepsilon=\frac{Q}{\rho N_{\text {modern }}}
$$

where $Q$ is the local flux of ${ }^{10} \mathrm{Be}_{\text {met }}\left(\mathrm{at} \mathrm{cm}^{-2} \mathrm{y}^{-1}\right), \rho$ is the soil density $\left(\mathrm{g} \mathrm{cm}^{-3}\right)$ and $\mathrm{N}_{\text {modern }}$ is the ${ }^{10} \mathrm{Be}_{\text {met }}$ concentration at the surface $\left(\right.$ at $\left.\mathrm{g}^{-1}\right)$. By assuming that the closure age $(\mathrm{t})$ was the same at each site (TM and FH), then:

$$
[5] \frac{N_{\text {paleo } F H}}{N_{\text {modern } F H}}=\frac{N_{\text {paleo } T M}}{N_{\text {modern } T M}}
$$

Additionally, by assuming that $\mathrm{Q}$ is the same for both sites and that erosion is lock-stepped, by and reorganizing all variables ${ }^{6}$ :

$[6] E_{T M}=\frac{\rho_{F H} N_{\text {modern } F H}}{\rho_{T M} N_{\text {modern } T M}} E_{F H}$ 
and

$$
\text { [7] } E_{F H}=\frac{\ln \frac{a_{F H^{N} \text { modern } T M}}{a_{T M^{N} \text { modern } F H}}}{b_{F H}-b_{T M} \frac{\rho_{F H}{ }^{N} \operatorname{modern} F H}{\rho_{T M^{N}} \text { modern } T M}}
$$

$\mathrm{E}_{\mathrm{FH}}$ and $\mathrm{E}_{\mathrm{TM}}$ can then be used to calculate erosion-corrected minimum closure age using equations [2] and [3].

Assuming synchronous closure ages in the near-surface, ${ }^{10} \mathrm{Be}_{\text {met }}$ concentrations yielded erosion rate of $0.011 \mathrm{~m} \mathrm{Ma}^{-1}$ for TM01-97 (ETM) and $0.095 \mathrm{~m} \mathrm{Ma}^{-1}$ for FHDP2C (EFH; Table 1). These results are within regolith erosion rates in the $\operatorname{MDV}\left(0.01 \text { and } 3.0 \mathrm{~m} \mathrm{Ma}^{-1}\right)^{6,9,15}$. This suggests that the erosion-correction required for modeling closure ages is realistic. The closure age for the upper group at Friis Hills and Table Mountain calculated from the erosion-corrected $\mathrm{N}_{\text {paleo }}$ was $6.0 \pm 0.5 \mathrm{Ma}$.

Since the lower groups followed a linear regression where $b=0$ and the near-suface profiles overprinted the intermediate profiles, fitting an exponential equation to solve for $\mathrm{N}_{\text {paleo }}$ was not possible for the lower groups. The most realistic way to estimate $\mathrm{N}_{\text {paleo }}$ for the lower groups was to use the b-value from the upper groups and the same lock-stepped erosion rates. Closure age was then approximated using equation [2], which assumes that $\mathrm{N}_{\text {modern }}$ has not changed since closure. However, the closure age would increase if more ${ }^{10} \mathrm{Be}_{\mathrm{met}}$ was retained at the surface, had the climate been wetter in the past ${ }^{16}$. Based on the $\delta^{13} \mathrm{C}$ signal of C3 plants (-25.5 $\pm 0.7 \%$ VPDB), mean annual precipitation of 150 to $450 \mathrm{~mm} \mathrm{yr}^{-1}$ was estimated for Friis Hills during the mid-Miocene ${ }^{17}$. Using a modern analog for surface ${ }^{10} \mathrm{Be}_{\mathrm{met}}$ 
concentration with similar $\delta^{13} \mathrm{C}$ values, like Northern Sweden $\left(\delta^{13} \mathrm{C}=-26.0 \%\right.$ VPDB, ${ }^{10} \mathrm{Be}_{\mathrm{met}}=$ $2.0 \times 10^{8}$ at $\left.\mathrm{g}^{-1}\right){ }^{18,19},{ }^{10} \mathrm{Be}_{\text {met }}$ surface concentrations could have been approximately 4 times higher. The decay required to obtain current ${ }^{10} \mathrm{Be}_{\text {met }}$ concentrations can be modelled using the maximum $\mathrm{N}_{\text {modern. }}$. This age represents an estimate of maximum closure age for the lower group (assuming lock-stepped erosion). A maximum closure age of $\sim 12.0 \mathrm{Ma}$ for FHDP2C and $\sim 16.0$ Ma for TM01-97 for the lower section of the cores was calculated. However, these ages need to be treated with caution as they only represent a broad estimate of time required for ${ }^{10} \mathrm{Be}_{\mathrm{met}}$ concentrations in the $10^{8}$ at ${ }^{-1}$ range to decay to $10^{5}$ at $\mathrm{g}^{-1}$. Similarly, using the average ${ }^{10} \mathrm{Be}_{\text {met }}$ concentration for the deep samples as $\mathrm{N}_{\text {paleo }}$, the closure age at $40 \mathrm{~m}$ depth at Friis Hills was $~ 14.0$ Ma, same as the age of sediment. 


\section{Supplementary Figures}

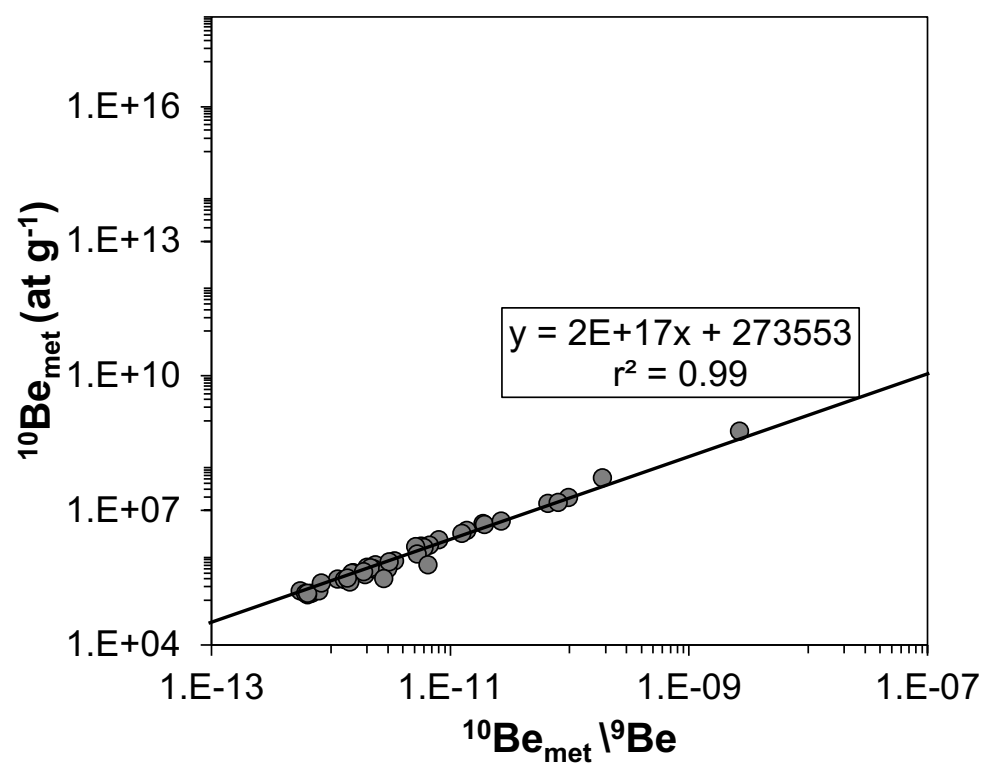

Fig. S1: ${ }^{10} \mathrm{Be}_{\text {met }}$ and ${ }^{10} \mathrm{Be}_{\text {met }} /{ }^{9} \mathrm{Be}$ biplot. Note: here, ${ }^{9} \mathrm{Be}$ is measured independently on a MP-AES

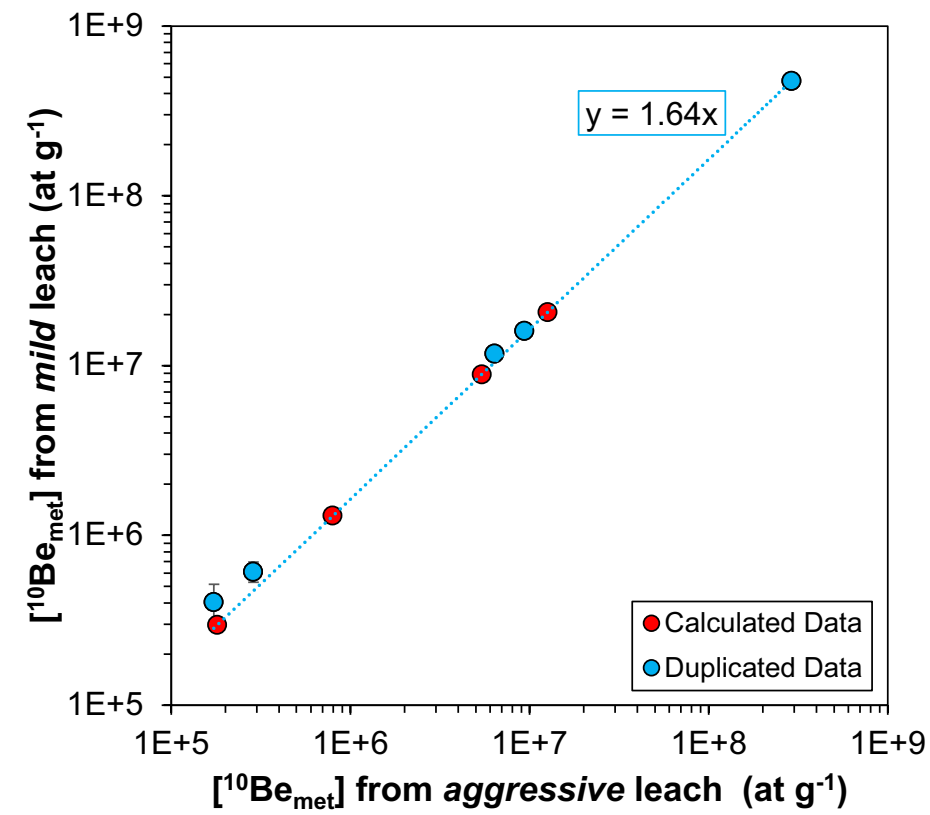

Fig. S2: Duplicate samples at Table Mountain show ${ }^{10} \mathrm{Be}_{\text {met }}$ concentrations measured by aggressive ${ }^{6}$ and mild leaching methods. Dataset in red offset using the duplicate function. 


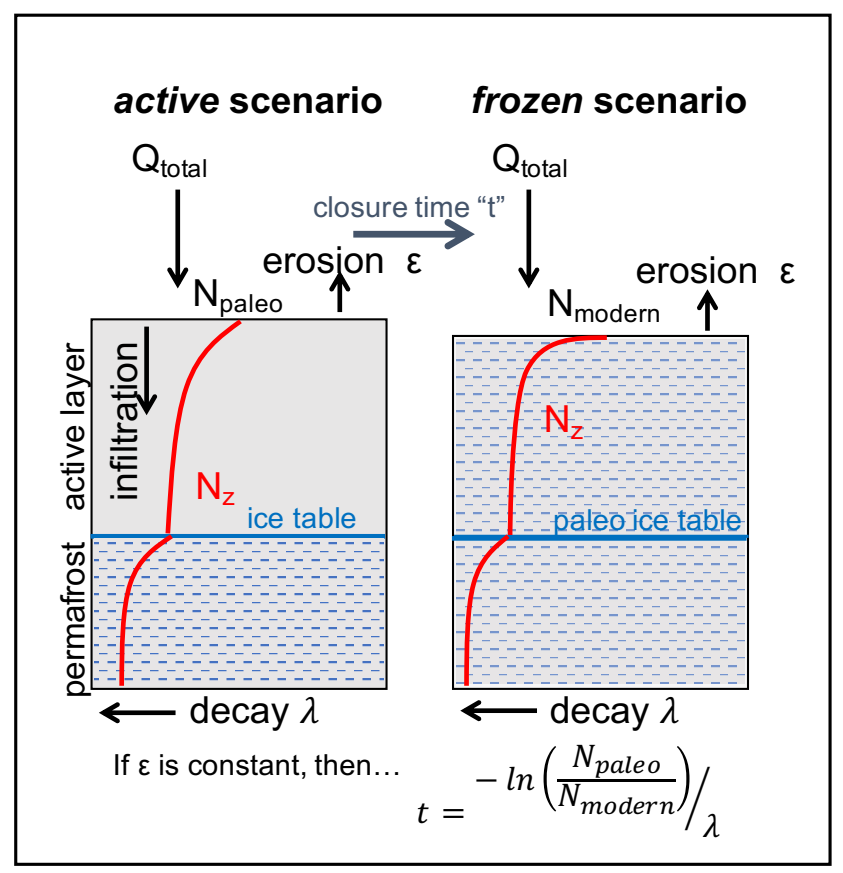

Fig. S3: Schematic representation of a ${ }^{10} \mathrm{Be}_{\text {met }}$ ground profile. The active scenario, where ${ }^{10} \mathrm{Be}_{\mathrm{met}}$ infiltration occurs is compared to the frozen scenario where ${ }^{10} \mathrm{Be}_{\text {met }}$ accumulates at the surface. Closure age represents the time since the system has been sealed-off from infiltration. 


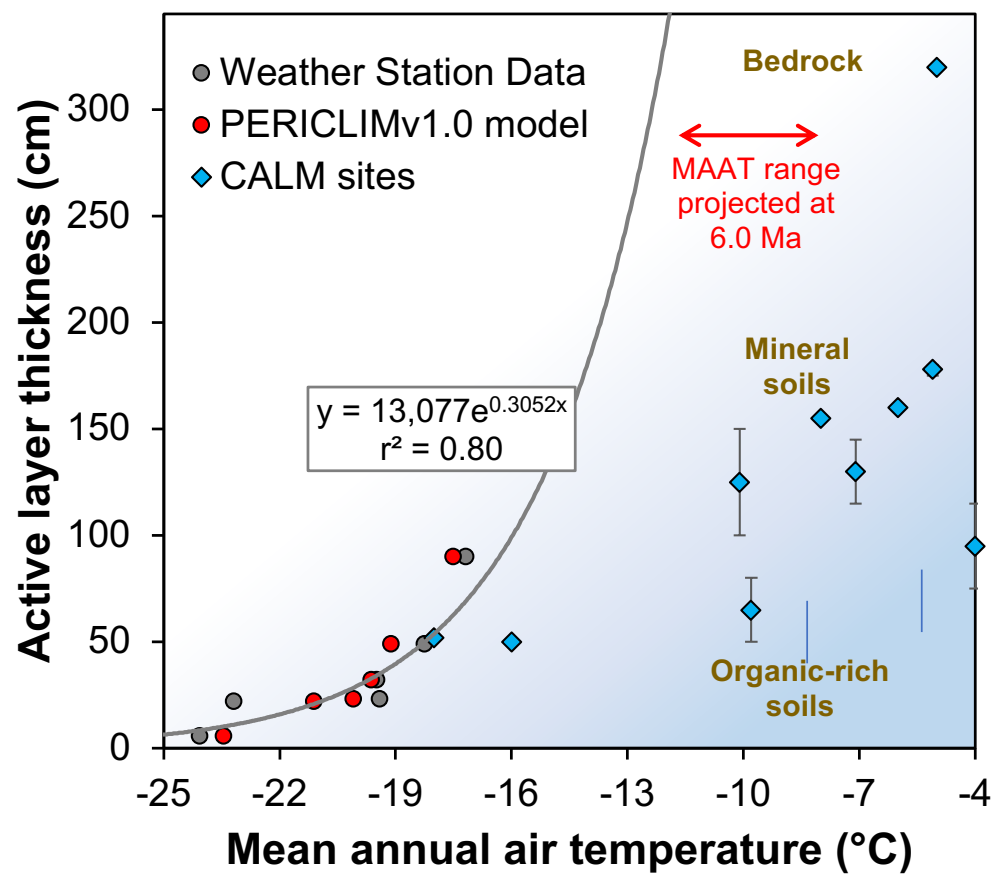

Fig. S4: Comparison between mean annual air temperature and active layer measurements at different sites in the $\mathrm{MDV}^{20}$ and values predicted by the PERICLIMv1.0. model ${ }^{21}$. Data is compared to selected Circumpolar Active Layer Monitoring (CALM) sites 1990-2011 (with data gaps) 


\section{Supplementary Tables}

Table S1: Measured and calculated values of ${ }^{10} \mathrm{Be}_{\text {met }}$ in preliminary sites at Friis Hills

\begin{tabular}{|c|c|c|c|c|c|}
\hline Sample ID & Depth (cm) & ${ }^{10} \mathrm{Be} /{ }^{9} \mathrm{Be}\left(10^{-12}\right)$ & Error (\%) & ${ }^{10} \mathbf{B e}_{\text {met }}\left(\right.$ at g $\left.^{-1}\right)$ & ${ }^{10} \mathrm{Be}_{\mathrm{met}}$ Error $\left(\right.$ at g $\left.^{-1}\right)$ \\
\hline \multicolumn{6}{|c|}{ 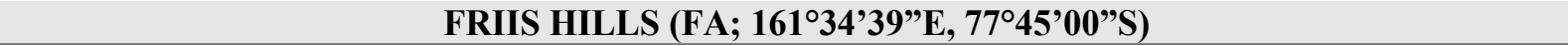 } \\
\hline FA-0 & 0 & 2.027 & 2.4 & $5.92 \mathrm{E}+07$ & $1.40 \mathrm{E}+06$ \\
\hline FA-5 & 5 & 0.199 & 7.5 & $5.85 \mathrm{E}+06$ & $4.41 \mathrm{E}+05$ \\
\hline FA-10 & 10 & 0.093 & 6.9 & $2.71 \mathrm{E}+06$ & $1.87 \mathrm{E}+05$ \\
\hline FA-30 & 30 & 0.093 & 9.9 & $2.70 \mathrm{E}+06$ & $2.67 \mathrm{E}+05$ \\
\hline FA-60 & 60 & 0.041 & 15.3 & $1.19 \mathrm{E}+06$ & $1.83 \mathrm{E}+05$ \\
\hline \multicolumn{6}{|c|}{ FRIIS HILLS (C2; $161^{\circ} 27^{\prime} 38^{\prime \prime} \mathrm{E}, 7^{\circ} 45$ '13”S) } \\
\hline $\mathrm{C} 2-0$ & 0 & 7.344 & 2.0 & $2.15 \mathrm{E}+08$ & $4.30 \mathrm{E}+06$ \\
\hline $\mathrm{C} 2-5$ & 5 & 0.096 & 11.3 & $2.83 \mathrm{E}+06$ & $3.21 \mathrm{E}+05$ \\
\hline $\mathrm{C} 2-10$ & 10 & 0.114 & 10.0 & $3.33 \mathrm{E}+06$ & $3.32 \mathrm{E}+05$ \\
\hline $\mathrm{C} 2-32$ & 32 & 0.054 & 12.6 & $1.58 \mathrm{E}+06$ & $1.98 \mathrm{E}+05$ \\
\hline $\mathrm{C} 2-59$ & 59 & 0.051 & 20.6 & $1.50 \mathrm{E}+06$ & $3.09 \mathrm{E}+05$ \\
\hline \multicolumn{6}{|c|}{ 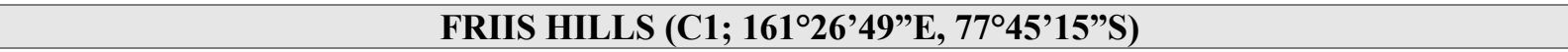 } \\
\hline $\mathrm{C} 1-0$ & 0 & 0.049 & 13.4 & $1.45 \mathrm{E}+06$ & $1.95 \mathrm{E}+05$ \\
\hline $\mathrm{C} 1-17$ & 17 & 0.030 & 27.7 & $8.85 \mathrm{E}+05$ & $2.45 \mathrm{E}+05$ \\
\hline \multicolumn{6}{|c|}{ LAB BLANK } \\
\hline Blank & N.A. & 0.003 & 57.7 & N.A. & N.A. \\
\hline
\end{tabular}


Table S2: Measured and calculated values of ${ }^{10} \mathrm{Be}_{\text {met }}$ at University Valley

\begin{tabular}{|c|c|c|c|c|c|}
\hline Sample ID & Depth (cm) & ${ }^{10} \mathrm{Be} /{ }^{9} \mathrm{Be}\left(10^{-12}\right)$ & Error (\%) & ${ }^{10} \mathbf{B e}_{\text {met }}\left(\right.$ at g $\left.^{-1}\right)$ & ${ }^{10} \mathrm{Be}_{\text {met }}$ Error $\left(\right.$ at $\left.\mathrm{g}^{-1}\right)$ \\
\hline \multicolumn{6}{|c|}{ 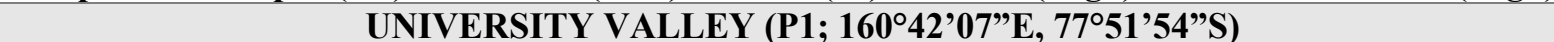 } \\
\hline P1 0-5 & 2.5 & 4.870 & 1.8 & $9.13 \mathrm{E}+08$ & $1.64 \mathrm{E}+07$ \\
\hline P1 15-20 & 17.5 & 1.980 & 1.8 & $3.65 \mathrm{E}+08$ & $6.58 \mathrm{E}+06$ \\
\hline P1 30 & 30 & 1.500 & 1.8 & $3.08 \mathrm{E}+08$ & $5.69 \mathrm{E}+06$ \\
\hline P1 43 & 43 & 1.300 & 2.0 & $2.49 \mathrm{E}+08$ & $5.01 \mathrm{E}+06$ \\
\hline P1 53 & 53 & 1.490 & 2.0 & $2.89 \mathrm{E}+08$ & $5.85 \mathrm{E}+06$ \\
\hline \multicolumn{6}{|c|}{ UNIVERSITY VALLEY (P2; 16042’32”'E, 7751’32”S) } \\
\hline P2 $0-5$ & 2.5 & 11.60 & 1.8 & $2.17 \mathrm{E}+09$ & $3.91 \mathrm{E}+07$ \\
\hline P2 20 & 20 & 0.330 & 3.0 & $6.25 \mathrm{E}+07$ & $1.88 \mathrm{E}+06$ \\
\hline P2 20-25 & 22.5 & 0.741 & 2.0 & $1.37 \mathrm{E}+08$ & $2.71 \mathrm{E}+06$ \\
\hline P2 34 & 34 & 0.609 & 1.8 & $1.13 \mathrm{E}+08$ & $2.03 \mathrm{E}+06$ \\
\hline $\mathrm{P} 242$ & 42 & 0.752 & 1.8 & $1.43 \mathrm{E}+08$ & $2.57 \mathrm{E}+06$ \\
\hline \multicolumn{6}{|c|}{ UNIVERSITY VALLEY (P8; 16043’34’'E, 7751'54’'S) } \\
\hline P8 2 & 2 & 2.70 & 1.8 & $4.99 \mathrm{E}+08$ & $8.99 \mathrm{E}+06$ \\
\hline P8 16 & 16 & 0.121 & 2.5 & $2.45 \mathrm{E}+07$ & $6.23 \mathrm{E}+05$ \\
\hline P8 26 & 26 & 0.121 & 2.7 & $2.23 \mathrm{E}+07$ & $6.17 \mathrm{E}+05$ \\
\hline \multicolumn{6}{|c|}{ LAB BLANK } \\
\hline Blank & N.A. & 0.001 & 1.7 & N.A. & N.A. \\
\hline
\end{tabular}


Table S3: Measured and calculated values of ${ }^{10} \mathrm{Be}_{\text {met }}$ at Friis Hills and Table Mountain (*2019 reruns)

\begin{tabular}{|c|c|c|c|c|c|}
\hline Sample ID & Depth (cm) & ${ }^{10} \mathrm{Be} /{ }^{9} \mathrm{Be}\left(10^{-12}\right)$ & Error (\%) & ${ }^{10} \mathrm{Be}_{\text {met }}\left(\right.$ at $\left.^{-1}\right)$ & ${ }^{10} \mathbf{B e}_{\text {met }}$ Error $\left(\right.$ at g $\left.^{-1}\right)$ \\
\hline \multicolumn{6}{|c|}{ FRIIS HILLS (FHDP2C; $\left.161^{\circ} 27^{\prime} 21^{\prime \prime} \mathrm{E}, 7^{\circ} 45^{\prime} 17^{\prime \prime S}\right)$} \\
\hline $2-\mathrm{C} 0-1$ & 1 & 2.294 & 1.5 & $4.37 \mathrm{E}+07$ & $8.07 \mathrm{E}+05$ \\
\hline $2-\mathrm{C} 0-2$ & 5 & 0.200 & 3.5 & $4.11 \mathrm{E}+06$ & $1.76 \mathrm{E}+05$ \\
\hline $2-\mathrm{C} 0-3$ & 10 & 0.209 & 3.6 & $3.94 \mathrm{E}+06$ & $1.76 \mathrm{E}+05$ \\
\hline $2-\mathrm{C} 0-4$ & 15 & 0.157 & 3.9 & $2.88 \mathrm{E}+06$ & $1.41 \mathrm{E}+05$ \\
\hline $2-\mathrm{C} 0-5$ & 20 & 0.258 & 3.3 & $4.67 \mathrm{E}+06$ & $1.90 \mathrm{E}+05$ \\
\hline $2 \mathrm{C}-\mathrm{C} 1-2$ & 38 & 0.125 & 4.8 & $2.49 \mathrm{E}+06$ & $1.50 \mathrm{E}+05$ \\
\hline 2C-C1-10 & 59.5 & 0.085 & 6.1 & $1.82 \mathrm{E}+06$ & $1.38 \mathrm{E}+05$ \\
\hline $2 \mathrm{C}-\mathrm{C} 1-18$ & 78 & 0.070 & 5.6 & $1.38 \mathrm{E}+06$ & $9.71 \mathrm{E}+04$ \\
\hline 2C-C1-22 & 97 & 0.062 & 7.8 & $1.30 \mathrm{E}+06$ & $1.27 \mathrm{E}+05$ \\
\hline 2C-C1-29 & 116.5 & 0.067 & 5.9 & $1.21 \mathrm{E}+06$ & $8.98 \mathrm{E}+04$ \\
\hline $2 \mathrm{C}-\mathrm{C} 2-8$ & 135.5 & 0.052 & 8.1 & $1.25 \mathrm{E}+06$ & $1.27 \mathrm{E}+05$ \\
\hline $2 \mathrm{C}-\mathrm{C} 2-26$ & 189.5 & 0.024 & 15.9 & $4.96 \mathrm{E}+05$ & $1.02 \mathrm{E}+05$ \\
\hline $2 \mathrm{C}-\mathrm{C} 3-3$ & 246 & 0.020 & 12.7 & $2.98 \mathrm{E}+05$ & $5.09 \mathrm{E}+04$ \\
\hline $2 C-C 3-16$ & 286.5 & 0.019 & 11.5 & $4.35 \mathrm{E}+05$ & $6.54 \mathrm{E}+04$ \\
\hline $2 \mathrm{C}-\mathrm{C} 4-9$ & 336.5 & 0.023 & 14.4 & $4.02 \mathrm{E}+05$ & $7.63 \mathrm{E}+04$ \\
\hline 2C-C4-20 & 364.5 & 0.011 & 15.8 & $2.33 \mathrm{E}+05$ & $5.05 \mathrm{E}+04$ \\
\hline $2 \mathrm{C}-\mathrm{C} 5-2$ & 459 & 0.024 & 13.4 & $4.25 \mathrm{E}+05$ & $7.45 \mathrm{E}+04$ \\
\hline 2C-C5-11 & 490 & 0.017 & 12.1 & $3.29 \mathrm{E}+05$ & $5.34 \mathrm{E}+04$ \\
\hline $2 \mathrm{C}-\mathrm{C} 5-20$ & 510.5 & 0.016 & 13.0 & $3.20 \mathrm{E}+05$ & $5.57 \mathrm{E}+04$ \\
\hline \multicolumn{6}{|c|}{ FRIIS HILLS (FHDP3A; 161 ${ }^{\circ} 26^{\prime} 46 ” \mathrm{E}, 7^{\circ} 45^{\prime} 09 ” S$ ) } \\
\hline $3 \mathrm{~A}-\mathrm{C} 27-1$ & 3717.5 & 0.014 & 13.7 & $2.28 \mathrm{E}+05$ & $4.34 \mathrm{E}+04$ \\
\hline $3 \mathrm{~A}-\mathrm{C} 27-2$ & 3736.5 & 0.013 & 15.3 & $2.03 \mathrm{E}+05$ & $4.36 \mathrm{E}+04$ \\
\hline $3 \mathrm{~A}-\mathrm{C} 28-1$ & 3785.5 & 0.007 & 23.8 & $1.28 \mathrm{E}+05$ & $4.54 \mathrm{E}+04$ \\
\hline $3 \mathrm{~A}-\mathrm{C} 33-1$ & 4265.5 & 0.008 & 16.5 & $1.11 \mathrm{E}+05$ & $2.85 \mathrm{E}+04$ \\
\hline $3 \mathrm{~A}-\mathrm{C} 33-2$ & 4307 & 0.009 & 15.1 & $1.25 \mathrm{E}+05$ & $2.88 \mathrm{E}+04$ \\
\hline $3 \mathrm{~A}-\mathrm{C} 33-3$ & 4333.75 & 0.008 & 18.1 & $1.03 \mathrm{E}+05$ & $2.94 \mathrm{E}+04$ \\
\hline $3 \mathrm{~A}-\mathrm{C} 33-4$ & 4337 & 0.021 & 14.8 & $3.45 \mathrm{E}+05$ & $6.78 \mathrm{E}+04$ \\
\hline $3 \mathrm{~A}-\mathrm{C} 33-5$ & 4341.5 & 0.007 & 22.4 & $1.12 \mathrm{E}+05$ & $3.85 \mathrm{E}+04$ \\
\hline $3 \mathrm{~A}-\mathrm{C} 33-6$ & 4344.5 & 0.008 & 18.3 & $1.11 \mathrm{E}+05$ & $3.14 \mathrm{E}+04$ \\
\hline $3 \mathrm{~A}-\mathrm{C} 34-1$ & 4411.5 & 0.010 & 16.8 & $1.92 \mathrm{E}+05$ & $4.54 \mathrm{E}+04$ \\
\hline \multicolumn{6}{|c|}{ TABLE MOUNTAIN (TM01; 7757’36”S, 161'57'15”E/TM97) } \\
\hline TM01-S1* & 3 & 22.667 & 1.5 & $4.75 \mathrm{E}+08$ & $8.77 \mathrm{E}+06$ \\
\hline TM01-S2* & 27 & 0.856 & 2.3 & $1.60 \mathrm{E}+07$ & $4.49 \mathrm{E}+05$ \\
\hline TM01-9* & 140.5 & 0.545 & 2.9 & $1.18 \mathrm{E}+07$ & $4.24 \mathrm{E}+05$ \\
\hline TM01-25* & 339 & 0.033 & 10.7 & $6.13 \mathrm{E}+05$ & $8.41 \mathrm{E}+04$ \\
\hline TM01-37* & 463.5 & 0.023 & 20.9 & $4.06 \mathrm{E}+05$ & $1.11 \mathrm{E}+05$ \\
\hline TM01-42 & 525.5 & 0.041 & 13.0 & $8.62 \mathrm{E}+05$ & $1.42 \mathrm{E}+05$ \\
\hline TM01-44 & 575 & 0.028 & 15.2 & $5.82 \mathrm{E}+05$ & $1.14 \mathrm{E}+05$ \\
\hline TM01-48 & 607 & 0.014 & 15.6 & $2.45 \mathrm{E}+05$ & $5.25 \mathrm{E}+04$ \\
\hline TM97-7B-1 & 745 & 0.030 & 16.4 & $4.98 \mathrm{E}+05$ & $1.06 \mathrm{E}+05$ \\
\hline TM97-7B-2 & 885 & 0.015 & 14.4 & $2.42 \mathrm{E}+05$ & $4.81 \mathrm{E}+04$ \\
\hline \multicolumn{6}{|c|}{ LAB BLANKS } \\
\hline Blank 1 & N.A. & 0.008 & 18.2 & N.A. & N.A. \\
\hline Blank 2 & N.A. & 0.004 & 30.1 & N.A. & N.A. \\
\hline Blank 3 & N.A. & 0.001 & 53.9 & N.A. & N.A. \\
\hline Blank 4 & N.A. & 0.003 & 37.8 & N.A. & N.A. \\
\hline
\end{tabular}


Table S4: Values of parameters used in PERICLIMv1.0 model

\begin{tabular}{ll}
\hline Input Parameters & Values \\
\hline Thaw depth $[\mathrm{m}]$ & $2.74-3.45$ \\
\hline Thawed ground thermal conductivity $\left[\mathrm{W} \mathrm{m}^{-1} \mathrm{~K}^{-1}\right]$ & $2.5^{\mathrm{a}}$ \\
\hline Volumetric ground moisture content $[-]$ & 0.3 \\
\hline Thawing n-factor $[-]$ & $\sim 3.0^{\mathrm{b}}$ \\
\hline Annual air temperature amplitude $\left[{ }^{\circ} \mathrm{C}\right]$ & $37^{\mathrm{c}}$ \\
\hline Period of air temperature oscillations $[\mathrm{d}]$ & 365 \\
\hline${ }^{\mathrm{a}}$ retrieved from ${ }^{22}$ for sandy soils & \\
${ }^{\mathrm{b}}$ determined from wet bare Antarctic ground ${ }^{23,24}$ & \\
${ }^{\mathrm{c}}$ retrieved from &
\end{tabular}




\section{Supplementary References}

1 Wittmann, H. et al. The dependence of meteoric $10 \mathrm{Be}$ concentrations on particle size in Amazon River bed sediment and the extraction of reactive $10 \mathrm{Be} / 9 \mathrm{Be}$ ratios. Chemical Geology 318, 126-138 (2012).

2 Tessier, A., Campbell, P. G. \& Bisson, M. Sequential extraction procedure for the speciation of particulate trace metals. Analytical chemistry 51, 844-851 (1979).

3 Bourles, D., Klinkhammer, G., Campbell, A., Brown, E. \& Edmond, J. Beryllium in marine pore waters: geochemical and geochronological implications. Nature 341, 731-733 (1989).

4 Guelke-Stelling, M. \& von Blanckenburg, F. Fe isotope fractionation caused by translocation of iron during growth of bean and oat as models of strategy I and II plants. Plant and soil 352, 217-231 (2012).

5 Nishiizumi, K. et al. Absolute calibration of 10Be AMS standards. Nuclear Instruments and Methods in Physics Research Section B: Beam Interactions with Materials and Atoms 258, 403-413 (2007).

6 Dickinson, W. W., Schiller, M., Ditchburn, B. G., Graham, I. J. \& Zondervan, A. Meteoric Be-10 from Sirius Group suggests high elevation McMurdo Dry Valleys permanently frozen since 6 Ma. Earth and Planetary Science Letters 355, 13-19, doi:10.6073/pasta/9dda244e95ce8dfcdbd9b94d2289ef1d (2012).

7 Graham, I. et al. in Antarctica at the close of a millennium: proceedings of the 8th International Symposium on Antarctic Earth Sciences, Wellington 1999.

8 Schiller, M. Testing the antiquity of McMurdo Dry Valley soil surfaces with atmospheric $10 B e$ MSc Thesis thesis, Victoria University of Wellington, (2007).

9 Schiller, M., Dickinson, W., Ditchburn, R., Graham, I. \& Zondervan, A. Atmospheric 10Be in an Antarctic soil: Implications for climate change. Journal of Geophysical Research: Earth Surface 114 (2009).

10 Graham, I., Ditchburn, R. \& Whitehead, N. Be isotope analysis of a 0-500 ka loesspaleosol sequence from Rangitatau East, New Zealand. Quaternary International 76, 2942 (2001).

11 Ditchburn, R. G. \& Graham, I. Preparation procedures for the 10 Be analysis of marine deposits. (2002).

12 Valletta, R. D., Willenbring, J. K., Lewis, A. R., Ashworth, A. C. \& Caffee, M. Extreme decay of meteoric beryllium-10 as a proxy for persistent aridity. Scientific reports $\mathbf{5}, 17813$, doi:10.1038/srep17813 (2015).

13 Zondervan, A., Poletti, M., Purcell, C. R. \& Sparks, R. J. Accelerator and beamline upgrades at the AMS facility of GNS Science, New Zealand. Nuclear Instruments and Methods in Physics Research Section B: Beam Interactions with Materials and Atoms 259, 47-49 (2007).

14 Jull, A. T., Scott, E. M. \& Bierman, P. The CRONUS-Earth inter-comparison for cosmogenic isotope analysis. Quaternary Geochronology 26, 3-10 (2015).

15 Morgan, D. J., Putkonen, J., Balco, G. \& Stone, J. Degradation of glacial deposits quantified with cosmogenic nuclides, Quartermain Mountains, Antarctica. Earth Surface Processes and Landforms 36, 217-228 (2011).

16 Field, C. V., Schmidt, G. A., Koch, D. \& Salyk, C. Modeling production and climaterelated impacts on 10Be concentration in ice cores. Journal of Geophysical Research: Atmospheres 111 (2006). 
17 Kohn, M. J. Carbon isotope compositions of terrestrial C3 plants as indicators of (paleo) ecology and (paleo) climate. Proceedings of the National Academy of Sciences 107, 1969119695 (2010).

18 Ebert, K., Willenbring, J., Norton, K. P., Hall, A. \& Hättestrand, C. Meteoric 10Be concentrations from saprolite and till in northern Sweden: Implications for glacial erosion and age. Quaternary Geochronology 12, 11-22 (2012).

19 Jelinski, N. A. Problems of physical movement in soil genesis: application of meteoric Beryllium-10 as a component of multi-tracer analysis. (2014).

20 Adlam, L. S., Balks, M. R., Seybold, C. A. \& Campbell, D. I. in Annual Antarctic Conference. 45-52 (Cambridge University Press).

21 Uxa, T., Kř́žžek, M. \& Hrbáček, F. PERICLIMv1. 0: A model deriving palaeo-air temperatures from thaw depth in past permafrost regions. Geoscientific Model Development Discussions, 1-22 (2020).

22 Andersland, O. \& Anderson, D. Geotechnical engineering for cold regions. (1978).

23 Cannone, N. \& Guglielmin, M. Influence of vegetation on the ground thermal regime in continental Antarctica. Geoderma 151, 215-223 (2009).

24 Hrbáček, F., Nývlt, D. \& Láska, K. Active layer thermal dynamics at two lithologically different sites on James Ross Island, Eastern Antarctic Peninsula. Catena 149, 592-602 (2017).

25 Fountain, A. \& Doran, P. McMurdo Dry Valleys Friis Hills Meteorological Station Daily Averages. doi:10.6073/pasta/9dda244e95ce8dfcdbd9b94d2289ef1d (2016). 